\title{
Research Article \\ Review of the Bat Flies of Honduras, Central America (Diptera: Streblidae)
}

\author{
Carl W. Dick ${ }^{1,2}$ \\ ${ }^{1}$ Department of Biology, Western Kentucky University, Bowling Green, KY 42101, USA \\ ${ }^{2}$ Department of Zoology, Field Museum of Natural History, Chicago, IL 60605, USA
}

Correspondence should be addressed to Carl W. Dick; carl.dick@wku.edu

Received 7 June 2012; Accepted 28 January 2013

Academic Editor: D. D. Chadee

Copyright (c 2013 Carl W. Dick. This is an open access article distributed under the Creative Commons Attribution License, which permits unrestricted use, distribution, and reproduction in any medium, provided the original work is properly cited.

\begin{abstract}
Streblid bat flies are obligate and host-specific blood-feeding ectoparasites of bats. While the bat flies of some American countries are well studied (e.g., Panama, Venezuela), little is known about Honduran Streblidae. Accumulation of substantial numbers of specimens, from several different collections, has enabled a relatively thorough treatment of the fauna. This study is based on 2,236 specimens representing 17 genera and 43 species of Streblidae. Of those presently reported, 11 genera and 32 species are new records for Honduras, increasing the number of known genera and species by $65 \%$ and $74 \%$, respectively. Collection and host data are listed for all known Honduran streblid bat fly species. Comments regarding host associations and specificity, geographic distribution, and taxonomic problems are given in the species accounts.
\end{abstract}

\section{Introduction}

Streblid bat flies are a worldwide group of obligate, bloodfeeding ectoparasites of bats. The species tend to be host specific, with one fly species typically parasitizing one host species or a few closely related host species [1-3]. Some members of the streblid subfamily Nycterophiliinae are rather less host specific, often parasitizing two or more genera of hosts [4]. Distributional evidence suggests that they cospeciate with host species of bat, producing parallel phylogenies of host and parasite [5]. Streblids are often absent from bat species that roost solitarily or in temporary roosts [6]. Conversely, bat fly richness per host species seems generally to increase with roost size, duration, and the number of bats roosting there $[7,8]$. The dynamics associated with bat roosts as they pertain to the biology, ecology, and host specificity among streblid bat flies is a critically understudied area. Perhaps attributing to the fact that bat host species often harbor more than one species of Streblidae is the observation that some bat flies prefer particular areas (microhabitats, e.g., fur or wing membranes) on the host's body [1, 9-11].

The taxonomy of Neotropical streblid genera relies primarily on overall body form, the presence or absence of a ctenidium along the posteroventral margin of the head, gross characteristics of the wings, leg chaetotaxy, and details of the thorax, especially the mesonotal and transverse sutures, and male reproductive structures. Generic identification can always be made using a stereozoom microscope. Specieslevel identifications may often be made using low magnification, but some species (especially Trichobius spp.) are best identified using slide-mounted specimens examined using a high-power compound microscope. A simplified key to New World genera is available in [12]. Other generic keys are available in $[4,13,14]$. The single best key to most New World streblid species is [4]. For species-level keys, see [13, 15-19]. Guerrero listed characteristics for 36 species of Trichobius [16].

Few Streblidae have been recorded previously from Honduras, largely due to the lack of ectoparasite sampling in the country. Honduran specimens have been previously reported in three publications. Wenzel et al. [1] reported Strebla guajiro (García \& Casal) (as S. carolliae Wenzel) and S. wiedemanni Kolenati (as S. vespertilionis (Fabricius)). Wenzel [20] reported 12 species from Honduras but provided no data on specific records. Seven of the species are represented by specimens housed at the Field Museum of Natural History, Chicago (FMNH), and are considered valid records: Trichobius costalimai Guimaraes, 
T. parasiticus Gervais, Trichobioides perspicillatus (Pessôa \& Galvão), Megistopoda aranea (Coquillett), M. proxima (Séguy), Exastinion clovesi (Pessôa \& Guimarães), and Strebla hertigi Wenzel. The remaining five represent species whose presence in Honduras was inferred via geographical ranges [20]. These species included Trichobius dugesioides Wenzel, T. joblingi Wenzel, T. uniformis Curran, Paratrichobius longicrus (Miranda Ribeiro), and Speiseria ambigua Kessel. Peterson and Hůrka [21] reported Trichobius intermedius Peterson \& Hůrka. Finally, Wenzel [4] reported Anatrichobius scorzai Wenzel. Incidentally, four of the five species inferred to occur in Honduras [20] are documented in the present specimen collection. Thus, six genera and 11 species of Honduran streblids had been documented by specimens prior to this publication. With the few exceptions noted, all known Honduran streblid species are represented by specimens housed at FMNH.

Moreover, there are few published records for Streblidae from countries that neighbor Honduras, such as Mexico, Belize, Nicaragua, and El Salvador. Dick [22] provided a generic level treatment for the bat flies of Guatemala. Wenzel compiled an unpublished catalog of the Streblidae of El Salvador (R. L. Wenzel, pers. comm.). Many records of Costa Rican streblids are known, yet these are unpublished as well. The nearest well-known streblid fauna is that of Panama [1], wherein 66 species of Panamanian Streblidae were treated. Guerrero's [23] compilation listed Wenzel et al.s [1] species, plus three more for a total of 69 species for Panama.

\section{Materials and Methods}

The bulk of the specimens treated in this paper were collected by the author during 2001, as part of a survey project led by R. D. Bradley of Texas Tech University and R. A. Van Den Bussche and M. Hamilton of Oklahoma State University. During this expedition, 964 bats were collected at 15 localities. Bats were collected with nylon mist nets and by hand and usually kept individually in cloth bags. Because ectoparasite collection was not the main focus of the expedition, not all captured bats were sampled for parasites, and there were instances when cross-host contamination of parasites was likely. These instances are noted in the species accounts and addressed in the discussion. Bats were anesthetized with ethyl ether and brushed for ectoparasites, which were stored in vials of $95 \%$ ethanol. Streblid flies were collected from 242 individual bats. Most of the flies were studied under a dissection microscope. Others were slide-mounted in Canada balsam for examination under a compound microscope. Confirmations of identifications were made by comparison of the Honduran specimens to type specimens and other reference collections housed at the FMNH.

Specimens and specimen records for this project came from three primary sources. The TTU Honduras expedition yielded 381 records and 2051 specimens. Additionally, 47 records and 141 specimens were provided by T. J. McCarthy and R. P. Eckerlin, collected during the project "Mastozoolgía en el Núcleo de Centroamerica” (MANCA). Eighteen records and 44 specimens from the FMNH, representing new and previously reported specimens, were studied. Previously reported specimens (e.g., $[1,4,20,21]$ ) were reexamined. Fly identifications were made by the author, but historical FMNH specimens were originally identified by R. L. Wenzel. Thus, a total of 446 records and 2,236 specimens of Streblidae were examined as the basis of this paper. Most fly specimens have been deposited in the FMNH, but representative MANCA specimens were deposited at Carnegie Museum (CM), Pittsburgh, PA, USA, and a synoptic collection was deposited at TTU. Bat host vouchers exist for most of the parasite records; all flies collected during the TTU project can be traced to host bat specimens in the mammal collections of TTU. Flies collected during the MANCA project can be traced to bat specimens housed at CM or the American Museum of Natural History (AMNH), New York. Nomenclature used for bats generally follows Simmons [24]. The accounts below provide an overview of each streblid genus known from Honduras, presented by subfamily. Species accounts list streblid species and primary reference, records from Honduras, and comments when relevant. A concise list of all streblid species known from Honduras appears in Appendix A. A list of Honduran bat fly host associations is presented in Appendix B. A gazetteer of collection localities is presented in Table 1, which corresponds to the map of collection localities (Figure 1). Unless indicated otherwise, fly specimens were collected by the author.

\section{Species Accounts}

\subsection{Family Streblidae Kolenati, 1863}

\subsubsection{Subfamily Nycterophiliinae Wenzel, 1966}

Genus Nycterophilia Ferris, 1916

Nycterophilia Ferris, 1916:436.

This genus comprises five described species: $N$. coxata Ferris, N. fairchildi Wenzel, N. mormoopsis Wenzel, N. natali Wenzel, and $N$. parnelli Wenzel. Only $N$. coxata is known to occur in Honduras. Species in this genus are associated with bats of the families Mormoopidae, Natalidae, and Phyllostomidae (Leptonycteris Lydekker). Species of this genus are strongly compressed laterally, resembling fleas. The species are adapted to live inside the hair of their hosts [25].

\section{Nycterophilia coxata Ferris}

Nycterophilia coxata Ferris, 1916:437. Plate 22, Figures 5-6.

\section{Honduran Records (362 Specimens)}

COMAYAGUA: f1 from Sturnira lilium (E. Geoffroy), $4.8 \mathrm{~km} \mathrm{~N}, 8.7 \mathrm{~km} \mathrm{~W}$ Comayagua (Playitas), 10 July 2001.

COPÁN: m193, f164, 1 sex undetermined from Pteronotus parnellii (Gray), $20 \mathrm{~km}$ SE Santa Rosa de Copán, 17 July 2001.

OLANCHO: m1, f2 from $P$. parnellii, $4 \mathrm{~km}$ E Catacamas (Escuela de Sembrador), 20 July 2001. 


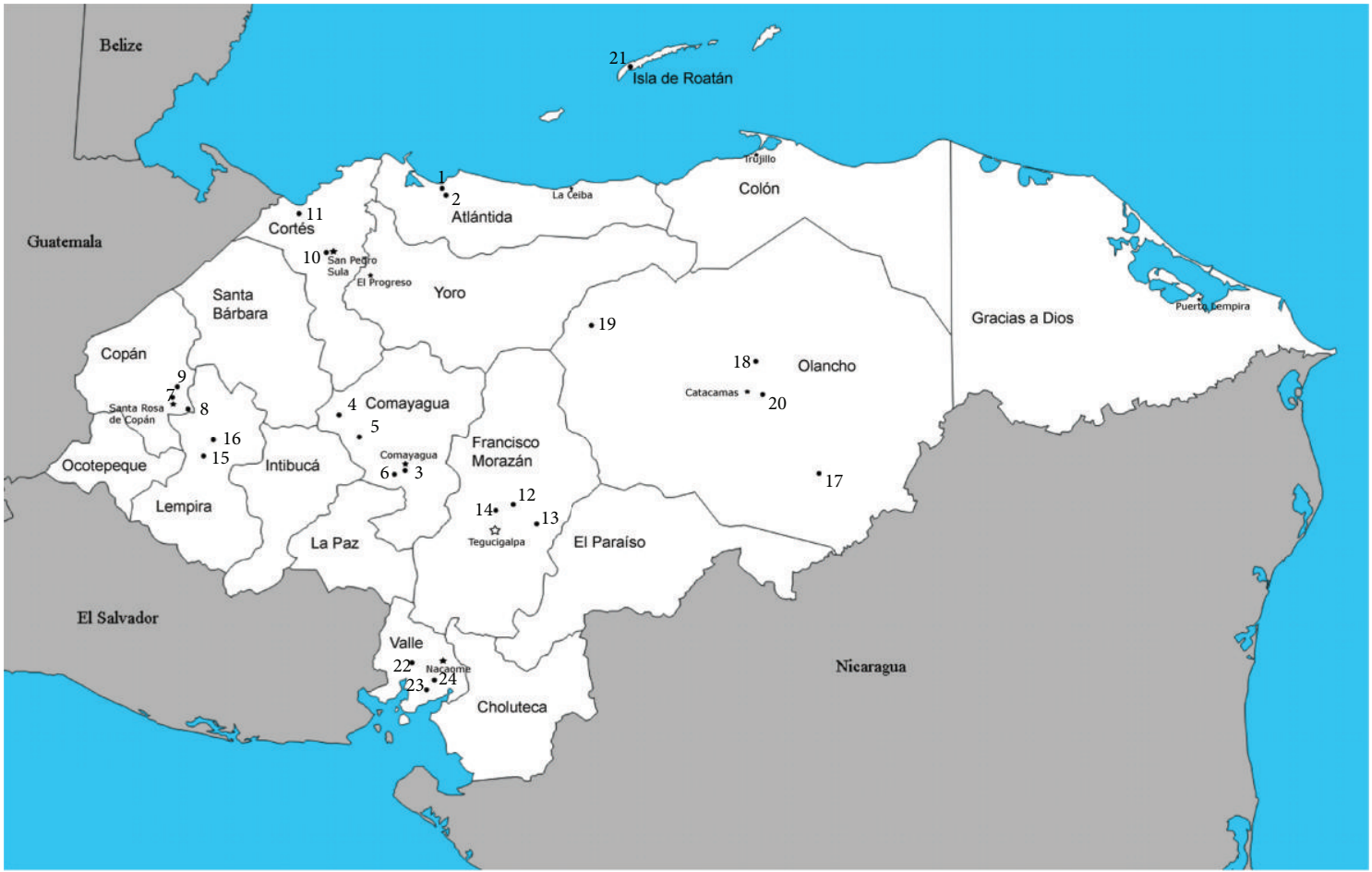

Figure 1: Map of Honduran bat fly collection localities. Locality numbers (numbered closed circles) correspond to specific localities in Gazetteer (Table 1).

In Honduras, the vast majority (99.7\%) of N. coxata specimens were associated with the mormoopid bat $P$. parnellii. The single specimen from $S$. lilium is regarded as a contaminant, as a specimen of P. gymnonotus Natterer was collected on the same day.

\subsubsection{Subfamily Streblinae Speiser, 1900}

Genus Anastrebla Wenzel, 1966

\section{Anastrebla Wenzel, 1966:627.}

This genus comprises five described species: $A$. caudiferae Wenzel, A. mattadeni Wenzel, A. modestini Wenzel, A. nycteridis Wenzel, and A. spurrelli Wenzel. Only A. modestini is known to occur in Honduras. Species of Anastrebla are typically associated with phyllostomid bats of the subfamily Glossophaginae.

\section{Anastrebla modestini Wenzel}

Anastrebla modestini Wenzel, 1966:629. Figures 138A, 139C, D.

\section{Honduran Record (1 Specimen)}

FRANCISCO MORAZÁN: f1 from Glossophaga soricina (Pallas), Parque Zoológico El Picacho, 5 July 2001.

Elsewhere (e.g., Panama and Venezuela $[1,4]$ ), this species is associated with Anoura geoffroyi Gray. Thus, its association with G. soricina is puzzling. Only one A. geoffroyi was collected on 18 July 2001.

\section{Genus Metelasmus Coquillett 1859}

Metelasmus Coquillett, 1907:292.

This genus comprises two species, Metelasmus pseudopterus and M. wenzeli Graciolli \& Dick, and only the former is known from Honduras. Metelasmus pseudopterus parasitizes certain species of large Artibeus Leach, including A. jamaicensis Leach, A. fimbriatus Gray, and A. planirostris Spix. Metelasmus wenzeli parasitizes Sturnira lilium in eastern Paraguay and southern Brazil. An undescribed species, similar to M. wenzeli, is known from Guatemalan Sturnira sp. It is probable that this undescribed species also occurs in Honduras. Species of Metelasmus are the only vestigially winged members of the subfamily Streblinae. The species are dorsoventrally compressed and possess a ctenidium of rearward facing spines on the posteroventral margin of the head. The species appear to be adapted to live within the fur of their hosts [24].

\section{Metelasmus pseudopterus Coquillett}

Metelasmus pseudopterus Coquillett, 1907:292.

\section{Honduran Records (4 Specimens)}

ATLÁNTIDA: ml, f1 from Artibeus jamaicensis, Jardin Botanico Lancetilla, 12 July 2001; f1 from Carollia sowelli Baker et al., Jardin Botanico Lancetilla, 
12 July 2001; m1 from A. lituratus (Olfers), Jardin Botanico Lancetilla, 14 July 2001.

This species is a characteristic parasite of Artibeus jamaicensis in the Central and northern South America and of A. planirostris and A. fimbriatus in southern South America. Graciolli and Dick [26] discussed its association with A. lituratus.

Genus Paraeuctenodes Pessôa and Guimarães, 1937

Paraeuctenodes Pessôa \& Guimarães, 1937:257.

Two described species belong to this genus, Paraeuctenodes longipes Pessôa \& Guimarães and P. similis Wenzel, and only the former is known from Honduras. In Honduras and Venezuela [4], the primary host species of $P$. longipes are Glossophaga spp., while the primary host of $P$. similis is Carollia perspicillata (Linnaeus). Both species of Paraeuctenodes are dorsoventrally flattened and possess a ctenidium of rearward facing spines on the posteroventral margin of the head. These characteristics appear to adapt the species to live within the fur of their hosts [25].

Paraeuctenodes longipes Pessôa and Guimarães

Paraeuctenodes longipes Pessôa and Guimarães, 1937:258.

Honduran Records (3 Specimens)

COMAYAGUA: f1 from Glossophaga commissarisi Gardner, 4.8 km N, 8.7 km W Comayagua (Playitas), 10 July 2001.

OLANCHO: m1, f1 from G. soricina, $4 \mathrm{~km}$ E Catacamas (Escuela de Sembrador), 20 July 2001.

Genus Strebla Wiedemann 1824

Strebla Wiedemann, 1824:19.

The genus Strebla comprises 25 described species and is second only to the genus Trichobius in number of species. Seven species of this genus are known to occur in Honduras. Species of Strebla are dorsoventrally flattened and possess a ctenidium of rearward facing spines on posteroventral margin of the head. This form appears to adapt species of Strebla to live inside the fur of the host [25].

Strebla chrotopteri Wenzel

Strebla chrotopteri Wenzel, 1976:144, Figures 60H, $64 \mathrm{E}$.

\section{Honduran Records (5 Specimens)}

LEMPIRA: m2 from Chrotopterus auritus (Peters), Parque Nacional Celaque, Centro de Visitantes, 11 October 1992, T. J. McCarthy, leg.; m2, f1 from C. auritus, Parque Nacional Celaque, Centro de Visitantes, 11 October 1992, J. V. Planz, leg.

This species is known only from the phyllostomine bat $C$. auritus.
Strebla curvata Wenzel

Strebla curvata Wenzel, 1976:148, Figures 60D, 63F.

Honduran Records (7 Specimens)

ATLÁNTIDA: f1 from Artibeus lituratus, Jardin Botanico Lancetilla, 12 July 2001; m2 from Glossophaga soricina, Jardin Botanico Lancetilla, 13 July 2001.

COMAYAGUA: f2 from G. soricina, $4.8 \mathrm{~km} \mathrm{~N}$, $8.7 \mathrm{~km}$ W Comayagua (Playitas), 10 July 2001.

OLANCHO: f1 from G. soricina, $3 \mathrm{~km} \mathrm{~N}$ Catacamas (Escuela Nacional de Agricultura), 20 July 2001; f1 from G. soricina, $4 \mathrm{kmE}$ Catacamas (Escuela de Sembrador), 20 July 2001.

Strebla curvata is a characteristic parasite of Glossophaga spp., particularly G. soricina, in both Honduras and Venezuela [4]. The species is remarkably similar to a congener, S. guajiro, which is a characteristic parasite of species of Carollia Gray.

Strebla diphyllae Wenzel

Strebla diphyllae Wenzel, 1966:613, Figures 124C, 133.

Honduran Records (2 Specimens)

ATLÁNTIDA: m1, f1 from Diphylla ecaudata, Lancetilla, 9 August 1969, R. K. LaVal, leg.

Strebla guajiro (García \& Casal)

Euctenodes guajiro García \& Casal, 1965:14, Figures 10-16.

\section{Honduran Records (13 Specimens)}

ATLÁNTIDA: f1 from Artibeus lituratus, Jardin Botanico Lancetilla, 12 July 2001; ml from Carollia perspicillata, Jardin Botanico Lancetilla, 12 July 2001; $\mathrm{m} 3$ from C. sowelli, Jardin Botanico Lancetilla, 12 July 2001; m1, f2 from C. sowelli, Jardin Botanico Lancetilla, 14 July 2001.

LEMPIRA: $\mathrm{m} 2$ from C. brevicauda (Schinz), Parque Nacional Celaque, Centro de Visitantes, 11 October 1992, J. V. Planz, leg.; f1 from C. brevicauda, Parque Nacional Celaque, Centro de Visitantes, 17 February 1998, R. P. Eckerlin, leg.

OLANCHO: $\mathrm{ml}$ from Glossophaga soricina, $3 \mathrm{~km} \mathrm{~N}$ Catacamas (Escuela Nacional de Agricultura), 20 July 2001.

ISLA ROATAN: m1 from unknown host, Coxen Hole, 9 January 1940, D. D. Davis, leg. (as S. carolliae Wenzel [1]).

The characteristic hosts of S. guajiro in Honduras were species of Carollia. In Venezuela, $98.5 \%$ of the 586 specimens collected there were taken from Carollia spp., and most of 
TABLE 1: Gazetteer of Honduran bat fly collection localities. Locality numbers correspond to map (Figure 1). Latitude and longitude are in decimal degrees. Specific localities with identical locality numbers are close in proximity, not warranting separate placement on the map (Figure 1).

\begin{tabular}{|c|c|c|c|c|}
\hline Department & Locality & Specific locality & Lat & Long \\
\hline Atlántida & 1 & Jardin Botanico Lancetilla & 15.7404 & -87.4572 \\
\hline Atlántida & 1 & Jardin Botanico Lancetilla (net 1) & 15.7457 & -87.4541 \\
\hline Atlántida & 1 & Jardin Botanico Lancetilla (net 2) & 15.7388 & -87.4552 \\
\hline Atlántida & 2 & Lancetilla & 15.6964 & -87.4319 \\
\hline Comayagua & 3 & Comayagua (Senasa) & 14.4551 & -87.6569 \\
\hline Comayagua & 4 & Cueva de Taulabe & 14.6949 & -87.9519 \\
\hline Comayagua & 5 & Siguatepeque & 14.5902 & -87.8600 \\
\hline Comayagua & 6 & $4.8 \mathrm{~km} \mathrm{~N}, 8.7$ km W Comayagua (Playitas) & 14.4280 & -87.7023 \\
\hline Copán & 7 & 0.5 km N, 1 km W Santa Rosa de Copán & 14.7880 & -88.7841 \\
\hline Copán & 8 & 20 km SE Santa Rosa de Copán & 14.7682 & -88.6926 \\
\hline Copán & 9 & 5 km NW Santa Rosa de Copán & 14.8532 & -88.7688 \\
\hline Cortés & 10 & Omoa, Fortaleza de San Francisco de Omoa & 15.5079 & -88.0355 \\
\hline Cortés & 11 & Santo Domingo, Sierra Omoa, 5.5 km ESE Cuyamel & 15.6587 & -88.1439 \\
\hline Francisco Morazán & 12 & Parque Nacional La Tigra & 14.2056 & -87.1160 \\
\hline Francisco Morazán & 13 & Parque Zoologia El Picacho & 14.1225 & -87.0236 \\
\hline Francisco Morazán & 14 & 12 mi N Tegucigalpa & 14.2044 & -87.2156 \\
\hline Lempira & 15 & Parque Nacional Celaque, Centro de Visitantes & 14.5500 & -88.6333 \\
\hline Lempira & 15 & Parque Nacional Celaque, Don Tomas & 14.5333 & -88.6500 \\
\hline Lempira & 16 & $3.5 \mathrm{mi} \mathrm{N}$ Gracias & 14.6506 & -88.5827 \\
\hline Olancho & 17 & Danli: $78 \mathrm{mi}$ ENE by E Rio Coco & 14.4652 & -85.6576 \\
\hline Olancho & 18 & Parque Nacional Agalta, Sendero a la Picucha & 15.0124 & -85.8615 \\
\hline Olancho & 19 & Parque Nacional de La Muralla, Los Cuatro Pavos & 15.0983 & -86.7333 \\
\hline Olancho & 20 & 3 km N Catacamas (Escuela Nacional de Agricultura) & 14.8258 & -85.8450 \\
\hline Olancho & 20 & 4 km E Catacamas (Escuela de Sembrador) & 14.8088 & -85.8428 \\
\hline Islas de la Bahía & 21 & Isla Roatán, Coxen Hole & 16.3293 & -86.5303 \\
\hline Valle & 22 & 13 km W, 3 km S Nacaome & 13.5152 & -87.5965 \\
\hline Valle & 23 & $3 \mathrm{~km} \mathrm{~N}, 12.5 \mathrm{~km}$ SW San Lorenzo & 13.4240 & -87.5446 \\
\hline Valle & 24 & 3 km N, 9 km SW San Lorenzo & 13.4484 & -87.5270 \\
\hline
\end{tabular}

these were from C. perspicillata [4]. The single specimen from A. lituratus is regarded as a contaminant, as specimens of $C$. perspicillata were collected on the same day.

Strebla hertigi Wenzel

Strebla hertigi Wenzel, 1966:596. Figures 122B, 125F, $127 \mathrm{~B}$.

\section{Honduran Records (5 Specimens)}

FRANCISCO MORAZON: m2, f2 from Phyllostomus discolor Wagner, $12 \mathrm{mi} \mathrm{N}$ Tegucigalpa, no date, “GHJ”, leg. ([20]; data compiled by author).

VALLE: $\mathrm{ml}$ from $P$. discolor, $3 \mathrm{~km} \mathrm{~N}, 12.5 \mathrm{~km} \mathrm{SW} \mathrm{San}$ Lorenzo, 7 July 2001.

Throughout its range, Strebla hertigi is a characteristic parasite of $P$. discolor. Within northern portions of its range, this species cooccurs with a congener, $S$. mirabilis, on the host species $P$. hastatus (Pallas). However, numerical dominance of each species varied depending on latitude [27]. No $P$. hastatus were collected during the present study, and no $S$. mirabilis were reported from any host species. Wenzel et al. [1] and Wenzel and Tipton [27] discussed the issue of competitive displacement for these species of Strebla on the host bats $P$. discolor and $P$. hastatus.

Strebla galindoi Wenzel

Strebla galindoi Wenzel, 1966:604. Figures 123D, 124F, 125D, 130.

Honduran Records (1 Specimen)

ATLÁNTIDA: $\mathrm{ml}$ from Tonatia saurophila Koopman \& Williams, Jardin Botanico Lancetilla, 12 July 2001.

Strebla kohlsi Wenzel

Strebla kohlsi Wenzel, 1966:618. Figure 123C.

Honduran Records (5 Specimens)

ATLÁNTIDA: m3, f2 from Lophostoma silvicolum d’Orbigny, Jardin Botanico Lancetilla, 14 July 2001. 
Strebla wiedemanni Kolenati

Hippobosca vespertilionis Fabricius, 1805:339. Suppressed by the ICZN, 1936:29.

Strebla wiedemannii Kolenati, 1856:46.

Honduran Records (69 Specimens)

ATLÁNTIDA: m1, f1 from Desmodus rotundus (E. Geoffroy), Lancetilla, 1 August 1969, R. Valdez, leg. (as S. vespertilionis (Fabricius) [1]; data compiled by author); m25, f17 from D. rotundus, Jardin Botanico Lancetilla, 12 July 2001; m11, f7 from D. rotundus, Jardin Botanico Lancetilla, 15 July 2001.

COPÁN: m2 from $D$. rotundus, no specific locality, May 1938, M. Ennis, leg. (as S. vespertilionis [1]; data compiled by author).

FRANCISCO MORAZON: $\mathrm{ml}$ from D. rotundus, Parque Nacional La Tigra, 6 July 2001.

LEMPIRA: f1 from D. rotundus, $3.5 \mathrm{mi} \mathrm{N}$ Gracias, 8 January 1938, P. O. McGrew, leg. (as S. vespertilionis [1]; data compiled by author); $\mathrm{m} 2$ from $D$. rotundus, Parque Nacional Celaque, Centro de Visitantes, 11 October 1992, J. V. Planz, leg.

VALLE: f1 from D. rotundus, $13 \mathrm{~km} \mathrm{W,} 3 \mathrm{~km} \mathrm{~S}$ Nacaome, 9 July 2001.

The characteristic host of Strebla wiedemanni in Honduras and elsewhere in the New World is the common vampire bat Desmodus rotundus.

\subsubsection{Subfamily Trichobinae Jobling, 1936}

Genus Anatrichobius Wenzel, 1966

Anatrichobius Wenzel, 1966:502.

This genus comprises two described species, Anatrichobius scorzai Wenzel and A. passosi Graciolli, only the former of which occurs in Honduras. These species are among the few New World streblids associated with vespertilionid bats; Anatrichobius spp. are restricted to species of the genus Myotis Kaup and appear restricted to elevations from 600 to $1900 \mathrm{~m} \mathrm{[28].}$

Anatrichobius scorzai Wenzel

Anatrichobius scorzai Wenzel, 1966:503. Figures 7678.

\section{Honduran Records (6 Specimens)}

FRANCISCO MORAZÁN: m1, f1 from Myotis keaysi J. A. Allen (RKL 2495-2521), 1 km W Talanga, 26 July 1969, R. K. LaVal, leg. [4].

OLANCHO: m3, f1 from M. keaysi (CM 118609), Parque Nacional de La Muralla, Los Cuatro Pavos, 18 October 1992, T. J. McCarthy, leg.
Elevational data for these records are not available, but they were likely collected in the Honduran highlands. The elevation of Talanga is approximately $840 \mathrm{~m}$, while Parque Nacional de La Muralla is a montane reserve, the highest point being $1,986 \mathrm{~m}$.

Genus Aspidoptera Coquillett, 1899

$$
\text { Aspidoptera Coquillett, 1899:334. }
$$

This genus comprises three species, Aspidoptera delatorrei Wenzel, A. falcata, and A. phyllostomatis [4, 23]; the latter two occur in Honduras. Species of this genus are restricted to phyllostomid bats of the subfamily Stenodermatinae.

Aspidoptera falcata Wenzel

Aspidoptera falcata Wenzel, 1976:104, Figure 42A.

Honduran Records (39 Specimens)

ATLÁNTIDA: m1, f1 from Sturnira lilium, Jardin Botanico Lancetilla, 12 July 2001.

COMAYAGUA: m9, f7 from S. lilium, $4.8 \mathrm{~km} \mathrm{~N}$, 8.7 km W Comayagua (Playitas), 10 July 2001.

LEMPIRA: $\mathrm{ml}$ from S. ludovici Anthony, Parque Nacional Celaque, Centro de Visitantes, 11 October, 1992, T. J. McCarthy, leg.; m2 from S. ludovici, Parque Nacional Celaque, Centro de Visitantes, 12 October 1992, T. J. McCarthy, leg.; ml from S. ludovici, Parque Nacional Celaque, Don Tomas, 12 February 1998, R. P. Eckerlin, leg.; f1 from S. ludovici, Parque Nacional Celaque, Don Tomas, 13 February 1998, R. P. Eckerlin, leg.; m7, f3 from S. ludovici, Parque Nacional Celaque, Centro de Visitantes, 17 February 1998, R. P. Eckerlin, leg.

OLANCHO: f1 from Noctilio leporinus (Linnaeus), $4 \mathrm{~km}$ E Catacamas (Escuela de Sembrador), 17 July 2001; m2, f1 from S. lilium, $4 \mathrm{~km}$ E Catacamas (Escuela de Sembrador), 19 July 2001; f1 from S. lilium, $3 \mathrm{~km} \mathrm{~N}$ Catacamas (Escuela Nacional de Agricultura), 20 July 2001.

VALLE: f1 from S. lilium, $13 \mathrm{~km} \mathrm{W,} 3 \mathrm{~km} \mathrm{~S} \mathrm{Nacaome,}$ 10 July 2001.

Aspidoptera falcata is a characteristic parasite of several species of Sturnira Gray, including S. lilium, S. ludovici, and S. tildae de la Torre. In Venezuela, $99.0 \%$ of the 755 A. falcata specimens collected there were taken from these three species of Sturnira [4]. The record from the fishing bat Noctilio leporinus almost certainly resulted from sampling contamination. Aspidoptera falcata is morphologically very similar to $A$. delatorrei and can be positively identified only by examining the postgonites (falciform in A. falcata).

Aspidoptera phyllostomatis (Perty)

Lipoptena phyllostomatis Perty, 1833:190, Figure 17, Plate 37. 


\section{Honduran Records (14 Specimens)}

ATLÁNTIDA: m5, f5 from Artibeus jamaicensis, Jardin Botanico Lancetilla, 12 July 2001; f1 from Glossophaga soricina, Jardin Botanico Lancetilla, 13 July 2001; m1, f2 from A. lituratus, Jardin Botanico Lancetilla, 13 July 2001.

The primary hosts of Aspidoptera phyllostomatis in Paraguay were Artibeus fimbriatus and A. planirostris, collectively hosting $93.1 \%$ of the 29 specimens. The remaining 2 of 29 (6.9\%) specimens were collected from 2 individuals of $A$. lituratus. The association between Aspidoptera phyllostomatis and Artibeus lituratus may be real, albeit rare. In Venezuela, 95.5\% of Aspidoptera phyllostomatis were associated with Artibeus jamaicensis/planirostris, but Wenzel [4] did not consider A. lituratus to be a host of this fly species.

\section{Genus Exastinion Wenzel, 1966}

\section{Exastinion Wenzel, 1966:558.}

This genus comprises three species, Exastinion clovisi (Pessôa \& Guimarães), E. deceptivum Wenzel, and E. oculatum Wenzel, of which only the former is known to occur in Honduras. All species in this genus parasitize species of Anoura Gray. Both E. clovisi and E. deceptivum occur on A. geoffroyi, but in some locations (e.g., Manu, Peru) the former species parasitizes hosts from lower elevations (1000-1920 m) while the latter species parasitizes hosts from higher elevations (1920-4137 m). There are to my knowledge no instances of cooccurrence of these species on the same individual bat (C. W. Dick, unpublished data).

\section{Exastinion clovisi (Pessôa \& Guimarães)}

Aspidoptera clovisi (Pessôa \& Guimarães), 1937:262. Figures 5-6.

\section{Honduran Records (5 Specimens)}

COMAYAGUA: m1, f2 from Anoura geoffroyi, Siguatepeque, 18 July 2001.

FRANCISCO MORAZÁN: m1, f1 from A. geoffroyi, $12 \mathrm{mi}$ N Tegucigalpa, 8 June 1963, D. C. Carter, leg. ([20]; data compiled by author).

In Venezuela, $98.8 \%$ of the 340 E. clovisi were collected from A. geoffroyi, A. latidens Handley, and A. caudifer (E. Geoffroy), in descending order.

Genus Mastoptera Wenzel, 1966

\section{Mastoptera Wenzel, 1966:512.}

This genus comprises two described species, Mastoptera guimaraesi Wenzel and M. minuta (Costa Lima), and appears to be restricted to phyllostomid bats of the subfamily Phyllostominae. This genus contains the smallest of New World streblid species, with some specimens of $M$. minuta measuring only $0.73 \mathrm{~mm}$ in total length [12]. The genus is in need of revision [4].
Mastoptera guimaraesi Wenzel

Mastoptera guimaraesi Wenzel, 1966: 514, Figures $82 \mathrm{C}, 83,84$.

Honduran Records (3 Specimens)

ATLÁNTIDA: m1, f2 from Phyllostomus hastatus, Lancetilla, 9 August 1969, R. Valdez \& R. K. LaVal, leg.

In Panama [1] and Venezuela [4], the characteristic host of this species is Phyllostomus hastatus.

Mastoptera minuta (Costa Lima)

Aspidoptera minuta Costa Lima, 1921:21, Figure 2, Plate 2.

Honduran Records (5 Specimens)

ATLÁNTIDA: m4, f1 from Lophostoma silvicolum, Jardin Botanico Lancetilla, 14 July 2001.

In Venezuela, the characteristic host of $M$. minuta is Lophostoma silvicolum (d'Orbigny) [4]. The taxonomy of Mastoptera species is complex and poorly understood, and Wenzel [4] noted that there were undescribed species within M. minuta.

Mastoptera sp. (Minuta Complex)

Honduran Records (23 Specimens)

ATLÁNTIDA: m14, f9 from Lophostoma brasiliense Peters, Jardin Botanico Lancetilla, 13 July 2001.

The 23 Honduran specimens were collected from one host individual of L. brasiliense. The taxonomy of Mastoptera species is complex and poorly understood, and Wenzel [4] noted that there were undescribed species within M. minuta. Here I refer specimens to $M$. minuta species complex. The group is in need of revision.

Genus Megistopoda Macquart, 1852

Megistopoda Macquart, 1852:332.

This genus comprises three described species: Megistopoda aranea, M. proxima, and M. theodori [4]. Wenzel [4] noted that the taxonomy of this genus is confused and in need of revision, as there are undescribed species within this genus. Wenzel [4] questioned the distinctness of $M$. theodori and stated that it might be synonymous with $M$. proxima. I consider the two species to be distinct (see $M$. theodori account below), but note that the proxima group of species contains several undescribed species. Megistopoda of the aranea type possess extremely elongated hind legs and very narrow wings and parasitize species of Artibeus (but not Dermanura spp.). Megistopoda of the proxima type (including $M$. theodori) possess less elongated hind legs and broader wings and parasitize species of Sturnira. However, recent specimens from western Ecuador document the existence of two other undescribed aranea type species, one from the west 
slope endemic Artibeus fraterculus Anthony and one from Platyrrhinus dorsalis (Thomas) (C. W. Dick, unpublished data). Collectively, species of Megistopoda are restricted to phyllostomid bats of the subfamily Stenodermatinae. All species possess elongated hind legs and a shield-like ventral thorax, which adapts them for movement over the fur of their hosts [25].

\section{Megistopoda aranea (Coquillett)}

Pterellipsis aranea Coquillett, 1899:344.

\section{Honduran Records (31 Specimens)}

ATLÁNTIDA: m4, f2 from Artibeus jamaicensis, Jardin Botanico Lancetilla, 12 July 2001; ml from A. lituratus, Jardin Botanico Lancetilla, 12 July 2001; m1 from Glossophaga soricina, Jardin Botanico Lancetilla, 15 July 2001.

LEMPIRA: m5, f2 from A. jamaicensis, Parque Nacional Celaque, Centro de Visitantes, 17 February 1998, R. P. Eckerlin, leg.

OLANCHO: $\mathrm{ml}$ from A. jamaicensis, $4 \mathrm{~km} \mathrm{E}$ Catacamas (Escuela de Sembrador), 19 July 2001; ml, f1 from A. jamaicensis, $4 \mathrm{~km}$ E Catacamas (Escuela de Sembrador), 20 July 2001; m1 from A. jamaicensis, $3 \mathrm{~km}$ E Catacamas (Escuela Nacional de Agricultura), 20 July 2001; m5, f2 from A. intermedius J. A. Allen, $3 \mathrm{~km}$ N Catacamas (Escuela Nacional de Agricultura), 20 July 2001.

ISLA ROATAN: m2, f2 from A. jamaicensis, "west end of island," 13 January 1994, R. P. Eckerlin, leg.

Unidentified Location: f1 from A. jamaicensis, "Tapasuna”, 1 December-1 January 1937-1938, P. O. McGrew, leg. ([20]; data compiled by author)

This species is a stenoxenous parasite of certain species of large Artibeus. In Venezuela, 97\% of the 546 specimens collected were associated with A. jamaicensis/planirostris [4]. In Paraguay, however, the primary hosts were Artibeus fimbriatus (70.2\% of 104 specimens) and A. planirostris (27.9\%).

\section{Megistopoda proxima (Séguy)}

Pterellipsis proxima Séguy, 1926:194, Figures 2-6.

Honduran Records (58 Specimens)

ATLÁNTIDA: m1 from Sturnira lilium, Jardin Botanico Lancetilla, 12 July 2001; f1 from Artibeus lituratus, Jardin Botanico Lancetilla, 12 July 2001; m1, f1 from A. lituratus, Jardin Botanico Lancetilla, 14 July 2001; $\mathrm{m} 1$ from Dermanura (= Artibeus) phaeotis (Miller), Jardin Botanico Lancetilla, 13 July 2001.

COMAYAGUA: m17, f13 from S. lilium, $4.8 \mathrm{~km} \mathrm{~N}$, $8.7 \mathrm{~km}$ W Comayagua (Playitas), 10 July 2001; m2, 1 sex undetermined from Glossophaga commissarisi, $4.8 \mathrm{~km} \mathrm{~N}, 8.7 \mathrm{~km} \mathrm{~W}$ Comayagua (Playitas), 10 July 2001.
OLANCHO: $\mathrm{m} 2$ from S. lilium, Danali, $78 \mathrm{mi}$ ENE by E Rio Coco, 15 May 1963, D. C. Carter, leg. ([20]; data compiled by author); m2, f5 from S. lilium, $4 \mathrm{~km}$ E Catacamas (Escuela de Sembrador), 19 July 2001; f1 from G. soricina, $4 \mathrm{~km}$ E Catacamas (Escuela de Sembrador), 19 July 2001.

VALLE: m6, f4 from S. lilium, $13 \mathrm{~km} \mathrm{W,} 3 \mathrm{~km} \mathrm{~S}$ Nacaome, 10 July 2001.

The characteristic host of $M$. proxima in Paraguay was $S$. lilium (hosting $98.1 \%$ of 372 specimens) [29]. In Venezuela, all of the 965 specimens were from S. lilium [4], but specimens from hosts other than $S$. lilium were simply referred to the $M$. proxima complex. Megistopoda proxima as currently described represents a complex of species [4], and in general, the true $M$. proxima are specific to S. lilium. This group of bat flies has not been studied in detail.

\section{Megistopoda theodori Wenzel}

Megistopoda theodori Wenzel, 1966:545. Figure 100B.

Honduran Records (52 Specimens)

ATLÁNTIDA: f1 from Uroderma bilobatum Peters, Jardin Botanico Lancetilla, 14 July 2001.

FRANCISCO MORAZON: m10, f8 from Sturnira ludovici, Parque Nacional La Tigra, 6 July 2001.

LEMPIRA: f3 from S. ludovici, Parque Nacional Celaque, Centro de Visitantes, 11 October 1992, T. J. McCarthy, leg.; m4, f2 from S. ludovici, Parque Nacional Celaque, Centro de Visitantes, 12 October 1992, T. J. McCarthy, leg.; m4, f1 from S. ludovici, Parque Nacional Celaque, Centro de Visitantes, 12 October 1992, J. V. Planz, leg.; f1 from S. ludovici, Parque Nacional Celaque, Centro de Visitantes, 13 October 1992, T. J. McCarthy, leg.; m3, f4 from $S$. ludovici, Parque Nacional Celaque, Don Tomas, 12 February 1998, R. P. Eckerlin, leg.; m1, f3 from $S$. ludovici, Parque Nacional Celaque, Don Tomas, 13 February 1998, R. P. Eckerlin, leg.; m2, f1 from $S$. ludovici, Parque Nacional Celaque, Centro de Visitantes, 17 February 1998, R. P. Eckerlin, leg.

OLANCHO: m3, f1 from S. ludovici, Parque Nacional Agalta, Sendero a la Picucha, 7 March 1998, R. P. Eckerlin, leg.

Wenzel [4] debated the validity of $M$. theodori and stated that it may be synonymous with $M$. proxima. A final decision was deferred until further studies had been undertaken. Moreover, Wenzel [4] stated that flies currently referred to M. proxima represent a complex of closely related species and that each host species may indeed harbor a distinct species of Megistopoda. Recent study concurs with [4] in this regard. It is clear that a thorough revision of Megistopoda is needed in order to resolve these issues. Although the thorax shows marked lateral compression as in M. proxima, the dorsal thoracic plate is less humped. I refer specimens from S. ludovici to $M$. theodori. 
Genus Neotrichobius Wenzel \& Aitken, 1966

Neotrichobius Wenzel \& Aitken, 1966:536.

Four described species belong to this genus and include Neotrichobius bisetosus Wenzel, N. delicatus MachadoAllison, N. ectophyllae Wenzel, and N. stenopterus Wenzel \& Aitken. Only the last species is known from Honduras. An undescribed species of Neotrichobius has been collected from Mesophylla macconnelli Thomas in La Selva, Costa Rica [30], and in Ecuador (C. W. Dick, unpublished data). Neotrichobius delicatus may represent a complex of species [4]. Neotrichobius spp. are typically associated with phyllostomid bats of the subfamily Stenodermatinae and with Rhinophylla pumilio Peters (Rhinophyllinae).

Neotrichobius stenopterus Wenzel \& Aitken

Neotrichobius stenopterus Wenzel \& Aitken, 1966:539. Figures 97-99.

Honduran Records (3 Specimens)

ATLÁNTIDA: f1 from Dermanura (= Artibeus) toltecus (Saussure), Jardin Botanico Lancetilla, 12 July 2001; $\mathrm{m} 2$ from D. phaeotis, Jardin Botanico Lancetilla, 13 July 2001.

Genus Noctiliostrebla Wenzel 1966

\section{Noctiliostrebla Wenzel 1966:560.}

This genus comprises four recognized species: Noctiliostrebla aitkeni Wenzel, N. dubia (Rudow), N. maai Wenzel, and $N$. traubi Wenzel $[4,23]$. Species of this genus are restricted to fishing or bulldog bats of the genus Noctilio Linnaeus (family Noctilionidae). Two species are known from $N$. leporinus and two from $N$. albiventris Desmarest, but based on data from Venezuela, the two species infesting each host species never cooccur on the same host individual [25]. Noctiliostrebla spp. possess vestigial wings and are rather similar in overall morphology.

Noctiliostrebla traubi Wenzel

Noctiliostrebla traubi Wenzel, 1966:565. Figures 106, 107B, D.

\section{Honduran Records (34 Specimens)}

OLANCHO: $\mathrm{ml}$ from Noctilio leporinus, $4 \mathrm{~km}$ E Catacamas (Escuela de Sembrador), 17 July 2001; m17, f16 from $N$. leporinus, $4 \mathrm{~km}$ E Catacamas (Escuela de Sembrador), 19 July 2001.

The characteristic host of Noctiliostrebla traubi in Honduras and elsewhere is the fishing bat Noctilio leporinus (Noctilionidae).

Genus Paradyschiria Speiser, 1900

Paradyschiria Speiser, 1900:55.
This genus comprises five species: Paradyschiria curvata Wenzel, P. fusca Speiser, P. lineata Kessel, P. parvula Falcoz, and $P$. parvuloides Wenzel $[4,23]$. Species of this genus are wholly restricted to fishing or bulldog bats of the genus Noctilio (family Noctilionidae). Two species parasitize only $N$. leporinus, while three species parasitize only $N$. albiventris. As with Noctiliostrebla spp., species of Venezuelan Paradyschiria never appear to cooccur on the same host individual [25]. Paradyschiria spp. are the only wingless streblid bat flies.

Paradyschiria fusca Speiser

Paradyschiria fusca Speiser, 1900:56, Figure 1, Plate 3.

Honduran Records (43 Specimens)

OLANCHO: m8, f5 from Noctilio leporinus, $4 \mathrm{~km} \mathrm{E}$ Catacamas (Escuela de Sembrador), 17 July 2001; m13, f17 from N. leporinus, $4 \mathrm{~km}$ E Catacamas (Escuela de Sembrador), 19 July 2001.

The characteristic host of $P$. fusca in Honduras and elsewhere is the fishing bat Noctilio leporinus.

Paradyschiria parvuloides Wenzel

Paradyschiria parvuloides Wenzel, 1966: 575. Figures 110D, 112C, D, 113B, 114.

Honduran Records (10 Specimens)

OLANCHO: m8, f2 from Noctilio albiventris, $4 \mathrm{~km} \mathrm{E}$ Catacamas (Escuela de Sembrador), 19 July 2001.

The characteristic host of $P$. parvula in Honduras and elsewhere is Noctilio albiventris.

Genus Paratrichobius Costa Lima, 1921

Paratrichobius Costa Lima, 1921:20.

This genus comprises six described species, Paratrichobius americanus Peterson \& Ross, P. dunni (Curran), P. longicrus (Ribeiro), P. lowei Wenzel, P. salvini Wenzel, and $P$. sanchezi Wenzel. All are known to be associated with bats of the phyllostomid subfamily Stenodermatinae. Paratrichobius spp. are fully winged but possess a shield-like ventral thorax very long hind legs; these characteristics appear to adapt these species to life in the fur and facilitate their evasive behavior of movement over the top of the fur. The taxonomy of this genus is confused and a revision is needed; in particular, the nominal species $P$. longicrus and $P$. salvini are most likely species complexes [4].

Paratrichobius dunni (Curran)

Speiseria dunni Curran, 1935:7, Figure 6.

Honduran Records (3 Specimens)

ATLÁNTIDA: f1 from Dermanura (=Artibeus) phaeotis, Jardin Botanico Lancetilla, 13 July 2001; m1, f1 from Uroderma bilobatum, Jardin Botanico Lancetilla, 14 July 2001. 
More than $98 \%$ of the 102 P. dunni collected in Venezuela were taken from Uroderma bilobatum and U. magnirostrum Davis [4]. Species of Dermanura host a unique species, $P$. lowei, and the present records from $D$. phaeotis are probably contaminants.

\section{Paratrichobius longicrus (Miranda Ribeiro)}

Trichobius longicrus Miranda Ribeiro, 1907:236, Plate 25.

\section{Honduran Records (14 Specimens)}

ATLÁNTIDA: m2, f3 from Artibeus lituratus, Jardin Botanico Lancetilla, 12 July 2001; f2 from A. lituratus, Jardin Botanico Lancetilla, 14 July 2001.

COMAYAGUA: $\mathrm{ml}$ from A. intermedius, $4.8 \mathrm{~km} \mathrm{~N}$, 8.7 km W Comayagua (Playitas), 10 July 2001; f2, f1 from A. intermedius, Siguatepeque, 18 July 2001.

LEMPIRA: f1 from Sturnira ludovici, Parque Nacional Celaque, Centro de Visitantes, 11 October 1992, T. J. McCarthy, leg.; $\mathrm{ml}$ from S. ludovici, Parque Nacional Celaque, Centro de Visitantes, 12 October 1992, T. J. McCarthy, leg.

VALLE: f1 from A. lituratus, $13 \mathrm{~km} \mathrm{~W}, 3 \mathrm{~km} \mathrm{~S}$ Nacaome, 10 July 2001.

As in Venezuela [4], the characteristic host of Paratrichobius longicrus in Paraguay is Artibeus lituratus (hosting 156 of 159 specimens; 98.1\%) [29]. Honduran records from hosts other than A. lituratus and A. intermedius are suspect. Simmons [24] considered $A$. intermedius a junior synonym of A. literatus. Artibeus lituratus is not known to harbor parasites of the genus Megistopoda, which are characteristic parasites of other species of Artibeus and Sturnira spp. Paratrichobius and Megistopoda may be ecological equivalents, being fairly similar in gross morphology with long hind legs. They differ, however, in that Paratrichobius spp. have fully functional wings while Megistopoda spp. have reduced and nonfunctional "strap-like" wings.

Paratrichobius sp. (salvini complex)

\section{Honduran Records (1 Specimen)}

ATLÁNTIDA: m1 from Platyrrhinus helleri (Peters), Jardin Botanico Lancetilla, 12 July 2001.

Paratrichobius salvini was described from the host Chiroderma salvini Dobson [1]. Forms from C. villosum Peters, C. trinitatum Goodwin, Platyrrhinus brachycephalus (Rouk \& Carter), and P. helleri are very similar to Paratrichobius salvini and were placed into the $P$. salvini species complex [4].

Genus Speiseria Kessel, 1925

Speiseria Kessel, 1925:19.

This genus comprises three described species: Speiseria ambigua, S. magnioculus Wenzel, and S. peytonae (Wenzel). Speiseria ambigua and $S$. peytonae are associated with bats of the genus Carollia (phyllostomid subfamily Carolliinae), while S. magnioculus is associated with Trachops cirrhosus (Spix) (phyllostomid subfamily Phyllostominae). Species are fully winged with long legs and are found in the furred regions of their hosts.

Speiseria ambigua Kessel

Speiseria ambigua Kessel, 1925:20, Figures 1-2, Plate 1.

Honduran Records (9 Specimens)

ATLÁNTIDA: m3, f3 from Carollia sowelli, Jardin Botanico Lancetilla, 12 July 2001; f1 from Mimon cozumelae Goldman, Jardin Botanico Lancetilla, 12 July 2001; $\mathrm{m} 2$ from C. sowelli, Jardin Botanico Lancetilla, 15 July 2001.

In Venezuela, Speiseria ambigua is a parasite of Carollia perspicillata, as $96 \%$ of those collected in Venezuela were from 220 C. perspicillata. Carollia brevicauda is host to S. peytonae; the specimens from $C$. sowelli cannot be distinguished from S. ambigua.

Speiseria peytonae Wenzel

Speiseria peytoni Wenzel, 1976:127. Figure 52B (emended by Wenzel, 1984).

Honduran Records (1 Specimen)

LEMPIRA: $\mathrm{ml}$ from Carollia brevicauda, Parque Nacional Celaque, Centro de Visitantes, 17 February 1998, R. P. Eckerlin, leg.

Males of S. peytonae are easily distinguished from those of $S$. ambigua by the form of the genitalia.

Genus Trichobioides Wenzel, 1966

Trichobioides Wenzel, 1966:510. cillatus.

This genus contains only one described species, T. perspi-

Trichobioides perspicillatus (Pessôa \& Galvão)

Trichobioides perspicillatus (Pessôa and Galvão) Wenzel, 1966:511, Figures 81, 82A.

Honduran Records (37 Specimens)

ATLÁNTIDA: f1 from Phyllostomus discolor, Lancetilla, 6 August 1969, R. Valdez and R. K. LaVal, leg. ([20]; data compiled by author)

COPÁN: m10, f8 from $P$. discolor, $20 \mathrm{~km} \mathrm{SE} \mathrm{Santa}$ Rosa de Copán, 17 July 2001.

CORTÉS: $\mathrm{ml}$ from $P$. discolor, Santo Domingo, 5.5 km ESE Cuyamel, 8 August 1988, T. J. McCarthy, leg.

FRANCISCO MORAZON: m3, f1 from $P$. discolor, $12 \mathrm{miN}$ Tegucigalpa, no date, "GHJ”, leg. (Wenzel, [20] 1970; data compiled by author). 
VALLE: $\mathrm{m} 3, \mathrm{f} 3$ from $P$. discolor, $3 \mathrm{~km} \mathrm{~N}, 12.5 \mathrm{~km} \mathrm{SW}$ San Lorenzo, 7 July 2001; m5, f2 from P. discolor, 13 km W, 3 km S Nacaome, 10 July 2001.

This species is a characteristic parasite of the phyllostomine bat Phyllostomus discolor. It is not known to occur on either of the other two species of Phyllostomus: P. elongatus (E. Geoffroy) and P. hastatus. All 37 Honduran specimens were collected from $P$. discolor, as were $97 \%$ of the 689 specimens collected in Venezuela [4].

\section{Genus Trichobius Gervais, 1844}

Trichobius Gervais, 1844:14.

The genus Trichobius currently comprises 68 described species and is the most diverse genus of the family Streblidae. The most recently described species were T. machadoallisoni Guerrero and T. anducei Guerrero [31]. Members of this genus parasitize a wide variety of bats, including representatives of the families Emballonuridae, Furipteridae, Molossidae, Mormoopidae, Natalidae, and Phyllostomidae. The genus has been divided into nine species groups or complexes [1, 4]: pallidus group (1 species), caecus group (7 species), uniformis group (4 species), major group (18 species), longipes group (8 species), dugesii group dugesii complex (12 species), dugesii group parasiticus complex (9 species), phyllostomae group (5 species), and the dunni group (4 species). Some of the described species of Trichobius are very distinct morphologically. Based on host associations and morphological affinities to other streblid genera, some workers feel that some if not all of the Trichobius species groups should be described as distinct genera (R. L. Wenzel, pers. comm.). The T. phyllostomae group has, based on morphological analysis, been shown to form a monophyletic group [32]. Yet other species are very similar morphologically and can be positively identified only by microslide mounting and examining under the high magnification of a compound microscope. The entire genus is in need of revision; it is predicted that the genus as currently constituted is widely paraphyletic. Thirteen species of Trichobius are known to occur in Honduras.

Trichobius caecus Edwards

Trichobius caecus Edwards, 1918:424.

Honduran Records (62 Specimens)

ATLÁNTIDA: m3, f7 from Pteronotus parnellii, Jardin Botanico Lancetilla, 15 July 2001.

COPÁN: m17, f21, 6 sex undetermined from $P$. parnellii, 20 km SE Santa Rosa de Copán, 17 July 2001; m2 from Phyllostomus discolor, $20 \mathrm{~km}$ SE Santa Rosa de Copán, 17 July 2001.

OLANCHO: m5, f1 from Pteronotus parnellii, $4 \mathrm{~km} \mathrm{E}$ Catacamas (Escuela de Sembrador), 20 July 2001.

Trichobius caecus is a member of the caecus group of species [4]. In Venezuela, 97\% of the 1,592 collected specimens were taken from the mormoopid bat $P$. parnellii.

\section{Trichobius costalimai Guimarães}

Trichobius costalimai Guimarães, 1938:660, Figure 10, Plate 3.

Honduran Records (75 Specimens)

ATLÁNTIDA: f2 from Phyllostomus discolor, Lancetilla, 6 August 1969, R. Valdez and R. K. LaVal, leg. ([20]; data compiled by author).

COPÁN: m21, f10 from $P$. discolor, $20 \mathrm{~km} \mathrm{SE} \mathrm{Santa}$ Rosa de Copán, 17 July 2001.

CORTÉS: $\mathrm{ml}$ from $P$. discolor, Santo Domingo, 5.5 km ESE Cuyamel, 8 August 1988, T. J. McCarthy, leg.

FRANCISCO MORAZON: m2, f1 from P. discolor, $12 \mathrm{mi} \mathrm{N}$ Tegucigalpa, no date, "GHJ”, leg. ([20; data compiled by author).

VALLE: $\mathrm{m} 5$, f5, 1 sex undetermined from $P$. discolor, $3 \mathrm{~km} \mathrm{~N}, 12.5 \mathrm{~km} \mathrm{SW}$ San Lorenzo, 7 July 2001; m16, f11 from $P$. discolor, $13 \mathrm{~km} \mathrm{W,} 3 \mathrm{~km}$ S Nacaome, 10 July 2001.

Trichobius costalimai is a member of the longipes group of species [4]. In Honduras, this species was collected only from Phyllostomus discolor; in Venezuela, 96\% of the 2,154 specimens collected were taken from $P$. discolor.

Trichobius diphyllae Wenzel

Trichobius diphyllae Wenzel, 1966: 492, Figures 68B, 73A.

Honduran Records (2 Specimens)

ATLÁNTIDA: f2 from Diphylla ecaudata, Lancetilla, 9 August 1969, R. K. LaVal, leg.

Trichobius diphyllae is a member of the parasiticus complex of the dugesii species group [4].

Trichobius dugesii Townsend

Trichobius dugesii Townsend, 1891:106.

Honduran Records (97 Specimens)

ATLÁNTIDA: f1 from Mimon cozumelae, Jardin Botanico Lancetilla, 12 July 2001; m2, f2 from Glossophaga soricina, Jardin Botanico Lancetilla, 13 July 2001; f1 from G. soricina, Jardin Botanico Lancetilla, 15 July 2001.

COMAYAGUA: f1 from G. soricina, $4.8 \mathrm{~km} \mathrm{~N}$, $8.7 \mathrm{~km} \mathrm{~W}$ Comayagua (Playitas), 9 July 2001; m10, f8 from G. soricina, $4.8 \mathrm{~km} \mathrm{~N}, 8.7 \mathrm{~km} \mathrm{~W}$ Comayagua (Playitas), 10 July 2001.

LEMPIRA: m2, f2 from G. commissarisi, Parque Nacional Celaque, Centro de Visitantes, 11 October 1992, J. V. Planz, leg.; ml from G. soricina, Parque Nacional Celaque, Centro de Visitantes, 13 October 1992, T. J. McCarthy, leg. 
OLANCHO: m3, f3 from G. soricina, $3 \mathrm{~km}$ N Catacamas (Escuela Nacional de Agricultura), 20 July 2001, C. W. Dick, leg.; f1 from G. soricina, $4 \mathrm{~km}$ E Catacamas (Escuela de Sembrador), 19 July 2001; m3 from G. soricina, $4 \mathrm{~km}$ E Catacamas (Escuela de Sembrador), 20 July 2001.

VALLE: $m 1$ from G. commissarisi, $3 \mathrm{~km} \mathrm{~N}, 12.5 \mathrm{~km} \mathrm{SW}$ San Lorenzo, 7 July 2001; $\mathrm{ml}$ from G. leachii Gray, $3 \mathrm{~km} \mathrm{~N}, 9 \mathrm{~km}$ SW San Lorenzo, 8 July 2001; m1, f1 from G. soricina, $3 \mathrm{~km} \mathrm{~N}$, $9 \mathrm{~km} \mathrm{SW} \mathrm{San} \mathrm{Lorenzo,} 8$ July 2001; m1, f1 from G. soricina, $13 \mathrm{~km} \mathrm{W,} 3 \mathrm{~km} \mathrm{~S}$ Nacaome, 9 July 2001.

Trichobius dugesii is a member of the dugesii complex of the dugesii group. The species appears to be stenoxenous, parasitizing several species of the glossophagine bat Glossophaga. In Honduras, it was collected from G. commissarisi, G. leachii, and G. soricina; in Venezuela, $97.7 \%$ of the 354 specimens collected were taken from $G$. longirostris Miller and $G$. soricina. The species cooccurs with a congener, $T$. uniformis.

Trichobius galei Wenzel

Trichobius galei Wenzel, 1966:449. Figures 57J-L.

Honduran Records (7 Specimens)

FRANCISCO MORAZON: m3, f3 from Natalus stramineus Gray, Parque Nacional La Tigra, 6 July 2001.

VALLE: $\mathrm{ml}$ from Glossophaga soricina, $13 \mathrm{~km} \mathrm{~W}$, $3 \mathrm{~km}$ S Nacaome, 9 July 2001.

Trichobius galei is a member of the caecus group of species [4]. Species of this group parasitize bats of the families Emballonuridae and Natalidae. In Panama [1] and Paraguay [29], T. galei was restricted to N. stramineus. In Venezuela, however, $98.5 \%$ of the 277 specimens collected were taken from the congener $N$. tumidirostris [4]. The Honduran record from $G$. soricina probably represents a contaminant.

\section{Trichobius hirsutulus Bequaert}

Trichobius hirsutulus Bequaert, 1933:572. Figures 30A, B.

\section{Honduran Records (10 Specimens)}

CORTÉS: m5, f5 from Myotis keaysi, Santo Domingo, $5.5 \mathrm{~km}$ ESE Cuyamel, 8 August 1988, T. J. McCarthy, leg.

Trichobius hirsutulus is a member of the major group of species. The major group of species is the only true "northern" radiation of Streblidae; species are known from North America, Mexico, Central America, and Antilles, but none from farther south than Peru. Previous to this report, the species was known only from México (Tamaulipas and Yucatán), from the vespertilionid Myotis nigricans Schinz.
Trichobius intermedius Peterson \& Hůrka

Trichobius intermedius Peterson \& Hůrka, 1974:1049.

Honduran Records (64 Specimens)

COMAYAGUA: m7, f3 from Artibeus intermedius, $4.8 \mathrm{~km} \mathrm{~N}, 8.7 \mathrm{~km} \mathrm{~W}$ Comayagua (Playitas), 10 July 2001; f2 from Sturnira lilium, $4.8 \mathrm{~km} \mathrm{~N}, 8.7 \mathrm{~km} \mathrm{~W}$ Comayagua (Playitas), 10 July 2001; m1, f1 from Glossophaga commissarisi, $4.8 \mathrm{~km} \mathrm{~N}, \quad 8.7 \mathrm{~km} \mathrm{~W}$ Comayagua (Playitas), 10 July 2001.

VALLE: m2, f1 from A. lituratus, $13 \mathrm{~km} \mathrm{W,} 3 \mathrm{~km} \mathrm{~S}$ Nacaome, 10 July 2001; m25, f21 from Artibeus inopinatus Davis and Carter, $13 \mathrm{~km} \mathrm{W,} 3 \mathrm{~km} \mathrm{~S}$ Nacaome, 9 July 2001.

SIN DEPARTAMENTO: $\mathrm{ml}$ from A. jamaicensis, “Tapasuna”, 1 December 1938, P. O. McGrew, leg. [21].

Trichobius intermedius is a member of the dugesii complex of the dugesii group of species. Throughout its range from Mexico, Antilles, to northern Central America, it is a characteristic parasite of large Artibeus species, particularly A. jamaicensis. Honduras appears to contain the terminus of its southern distribution. Extensive surveys have been undertaken in Costa Rica (C. W. Dick, R. M. Timm, R. L. Wenzel, unpublished data), Nicaragua (C. W. Dick, unpublished data), and Panama [1], but no T. intermedius were present in these collections.

Trichobius joblingi Wenzel

Trichobius joblingi Wenzel, 1966:481, Figures 68E, 70.

Honduran Records (142 Specimens)

ATLÁNTIDA: $\mathrm{ml}$ from Carollia castanea H. Allen, Jardin Botanico Lancetilla, 12 July 2001; m6, f1 from C. perspicillata, Jardin Botanico Lancetilla, 12 July 2001; $\mathrm{m} 23$, f13 from C. sowelli, Jardin Botanico Lancetilla, 12 July 2001; m17, f6 from C. sowelli, Jardin Botanico Lancetilla, 14 July 2001; m32, f24 from C. sowelli, Jardin Botanico Lancetilla, 15 July 2001; m1, f4 from $C$. subrufa, Jardin Botanico Lancetilla, 12 July 2001; m2, f2 from C. subrufa, Jardin Botanico Lancetilla, 15 July 2001.

COMAYAGUA: m3 from C. sowelli, Cueva de Taulabe, 11 July 2001.

LEMPIRA: $\mathrm{m} 2$ from $C$. brevicauda, Parque Nacional Celaque, Centro de Visitantes, 11 October 1992, J. V. Planz, leg.; m2 from C. brevicauda, Parque Nacional Celaque, Centro de Visitantes, 17 February 1998, R. P. Eckerlin, leg.

OLANCHO: $\mathrm{m} 3$ from C. sowelli, $4 \mathrm{~km} \mathrm{E}$ Catacamas (Escuela de Sembrador), 20 July 2001.

Trichobius joblingi is a member of the dugesii complex of the dugesii complex of species. The species is a characteristic parasite of C. perspicillata throughout the extent of its range. 
Trichobius longipes Rudow

Trichobius longipes Rudow, 1871:121.

Honduran Record (3 Specimens)

ATLÁNTIDA: m2 from Phyllostomus hastatus, Lancetilla, 9 August 1969, R. Valdez \& R. K. LaVal, leg.

CORTÉS: $\mathrm{ml}$ from $P$. hastatus, Omoa, Fortaleza de San Francisco de Omoa, 6 August 1988, T. J. McCarthy, leg.

Trichobius parasiticus Gervais

Trichobius parasiticus Gervais, 1844:14, Plate 43.

Honduran Records (858 Specimens)

ATLÁNTIDA: m125, f82 from Desmodus rotundus, Jardin Botanico Lancetilla, 12 July 2001; m12, f9 from $D$. rotundus, Jardin Botanico Lancetilla, 13 July 2001; m255, f268 from D. rotundus, Jardin Botanico Lancetilla, 15 July 2001; m7, f3 from Pteronotus parnellii, Jardin Botanico Lancetilla, 15 July 2001.

COMAYAGUA: $\mathrm{ml}$ from Artibeus intermedius, Siguatepeque, 18 July 2001.

COPÁN: f1 from Phyllostomus discolor, $20 \mathrm{~km} \mathrm{SE}$ Santa Rosa de Copán, 17 July 2001.

FRANCISCO MORAZON: m21, f17 from D. rotundus, Parque Nacional La Tigra, 6 July 2001.

LEMPIRA: m5, f2, 1 sex undetermined from $D$. rotundus, $3.5 \mathrm{miN}$ Gracias, 8 January 1938, P. O. McGrew, leg. ([20]; data compiled by author); m2, f3 from D. rotundus, Parque Nacional Celaque, Centro de Visitantes, 11 October 1992, J. V. Planz, leg.; m7, f4 from D. rotundus, Parque Nacional Celaque, Centro de Visitantes, 12 October 1992, S. R. Flores, leg.; m11, f14 from D. rotundus, Parque Nacional Celaque, Centro de Visitantes, 17 February 1998, R. P. Eckerlin, leg.

OLANCHO: $\mathrm{m} 1, \mathrm{f} 2$ from Rhynchonycteris naso (Wied-Neuwied), $4 \mathrm{kmE}$ Catacamas (Escuela de Sembrador), 19 July 2001.

VALLE: $\mathrm{m} 4$ from D. rotundus, $13 \mathrm{~km} \mathrm{~W}, 3 \mathrm{~km} \mathrm{~S}$ Nacaome, 9 July 2001.

Trichobius parasiticus is a characteristic parasite of the common vampire bat, Desmodus rotundus. Wenzel et al. [1] reported that on $D$. rotundus, T. furmani replaces $T$. parasiticus in some parts of South America.

Trichobius sparsus Kessel, 1925

Trichobius sparsus Kessell, 1925:17. Figures 7, 10.

Honduran Records (16 Specimens)

ATLÁNTIDA: m3, f2 from Pteronotus parnellii, Jardin Botanico Lancetilla, 15 July 2001; m6, f5 from Carollia sowelli, Jardin Botanico Lancetilla, 15 July 2001.
The association with C. sowelli is suspect; in Venezuela, all but one of 112 specimens were associated with $P$. parnellii [4]. The Jardin Botanico specimens were found on one bat of each species previously stated, captured at the same time in the same mist net.

Trichobius uniformis Curran

Trichobius uniformis Curran, 1935:10, Figure 8.

Honduran Records (37 Specimens)

ATLÁNTIDA: f1 from Artibeus lituratus, Jardin Botanico Lancetilla, 12 July 2001; f1 from Mimon cozumelae, Jardin Botanico Lancetilla, 12 July 2001; m7, f1 from Glossophaga soricina, Jardin Botanico Lancetilla, 13 July 2001; m6, f2 from G. soricina, Jardin Botanico Lancetilla, 15 July 2001.

COMAYAGUA: f1 from $G$. soricina, $4.8 \mathrm{~km} \mathrm{~N}$, 8.7 km W Comayagua (Playitas), 9 July 2001; $\mathrm{ml}$ from G. commissarisi, $4.8 \mathrm{~km} \mathrm{~N}, 8.7 \mathrm{~km} \mathrm{~W}$ Comayagua (Playitas), 10 July 2001; f3 from G. soricina, $4.8 \mathrm{~km} \mathrm{N,}$ 8.7 km W Comayagua (Playitas), 10 July 2001.

LEMPIRA: ml, f1 from G. commissarisi, Parque Nacional Celaque, Centro de Visitantes, 11 October 1992, J. V. Planz, leg.

OLANCHO: m3, f5 from G. soricina, $3 \mathrm{~km} \mathrm{~N} \mathrm{Cataca-}$ mas (Escuela Nacional de Agricultura), 20 July 2001; $\mathrm{m} 2$, f1 from G. soricina, $4 \mathrm{~km}$ E Catacamas (Escuela de Sembrador), 20 July 2001.

VALLE: $\mathrm{ml}$ from G. soricina, $13 \mathrm{~km} \mathrm{W,} 3 \mathrm{~km} \mathrm{~S}$ Nacaome, 9 July 2001.

This bat fly cooccurs on G. soricina with another congener, T. dugesii.

Trichobius Undescribed Species from Tonatia saurophila

Honduran Records (5 Specimens)

ATLÁNTIDA: m4, f1 from Tonatia saurophila, Jardin Botanico Lancetilla, 12 July 2001.

The existence of an undescribed species of Trichobius from the bat Tonatia saurophila was first noted by Wenzel (pers. comm.) and later by Miller and Tschapka [30]. Because a long series of specimens are known from Costa Rica (ca. 50 specimens), this species will be described elsewhere, in a treatment of the Costa Rican fauna.

\section{Discussion}

This paper provides the most comprehensive treatment to date of streblid bat flies known from Honduras and adds 11 genera (65\%) and 32 species (74\%) to the known Honduran fauna. From this treatment of a small but biologically important family of Diptera, it is clear that a great need exists in Honduras for systematic biodiversity surveys, during which museum specimens are prepared and identified and the rich fauna of Honduras is more fully described and explained. 
The need for baseline information on Honduran Streblidae cannot be overemphasized. At this time, 17 genera and 43 described species of streblid bat flies have been documented to occur in Honduras.

Streblid species richness in Honduras compares relatively well to other neotropical localities. Although relatively few comprehensive treatments of streblid flies exist for neotropical countries, those that do exist are insightful. In Panama, approximately 100 bat species were sampled yielding 66 fly species [1]. In Venezuela, approximately 130 bat species were sampled yielding 115 fly species [4]. In Paraguay, 54 bat species were sampled, yielding 31 fly species [29]. In the present study, approximately 45 species of bats were sampled, yielding 43 fly species. These trends in fly species richness relative to host species richness comport previous findings of positive correlation between fly and host richness values [29]. A relatively comprehensive treatment of Guatemalan bat flies yielded a fly species richness of 40 species, comparable to Honduras. However, the number of bats sampled for the Guatemalan collection is unknown [22].

The International Union for Conservation of Nature [33] lists 96 species of Chiroptera for Honduras. This is nearly identical to the 95 bat species reported for Guatemala [34]. Given the number of bat species in Honduras and assuming (1) that each of these is in fact host to fly species known from those hosts from other neotropical localities and (2) that each bat species is parasitized by unique species of Streblidae (e.g., $[2,3,35])$, it is possible to estimate the streblid bat fly species potentially in Honduras. Following neotropical hostparasite associations summarized in $[4,23]$, I estimate that the number of species in Honduras may be up to four times higher (ca. 170 spp.) than the number reported here.

Future work must be conducted in Honduras, particularly work that involves the collection of bats and their ectoparasites. Even simple specimen collection surveys would facilitate reasonable estimates of Honduras' biodiversity. Although Honduras is incredibly rich in biodiversity, knowledge of this biodiversity is little developed. Particularly in the light of pressure to modify natural habitat to suit ever expanding material needs of humankind, the time is right to make biodiversity surveys of Honduras, in order to assess and conserve its unique and important biodiversity.

\section{Appendices}

\section{A. Concise List of the 17 Genera and 43 Species of Streblid Bat Flies Known to Occur in Honduras}

New records (11 genera and 32 species) for Honduras are indicated by an asterisk as follows:

* Anastrebla modestini Wenzel, 1966

Anatrichobius scorzai Wenzel, 1966

* Aspidoptera falcata Wenzel, 1976

* Aspidoptera phyllostomatis (Perty), 1833

Exastinion clovisi (Pessôa \& Guimarães), 1937
* Mastoptera guimaraesi Wenzel, 1966

* Mastoptera minuta (Costa Lima), 1921

* Mastoptera sp. (minuta complex)

Megistopoda aranea (Coquillett), 1899

Megistopoda proxima (Séguy), 1926

* Megistopoda theodori Wenzel, 1966

* Metelasmus pseudopterus Coquillett, 1907

*Neotrichobius stenopterus Wenzel \& Aitken, 1966

*Noctiliostrebla traubi Wenzel, 1966

* Nycterophilia coxata Ferris, 1916

* Paradyschiria fusca Speiser, 1900

* Paradyschiria parvuloides Wenzel, 1966

*Paraeuctenodes longipes Pessôa \& Guimarães, 1937

* Paratrichobius dunni (Curran), 1935

* Paratrichobius longicrus (Miranda Ribeiro), 1907

${ }^{*}$ Paratrichobius sp. (salvini complex)

* Speiseria ambigua Kessel, 1925

* Speiseria peytonae Wenzel, 1976

* Strebla chrotopteri Wenzel, 1976

* Strebla curvata Wenzel, 1976

* Strebla diphyllae Wenzel, 1966

* Strebla galindoi Wenzel, 1966

Strebla guajiro (García \& Casal), 1965

Strebla hertigi Wenzel, 1966

* Strebla kohlsi Wenzel, 1966

Strebla wiedemanni Kolenati, 1856

Trichobioides perspicillatus (Pessôa \& Galvão), 1937

*Trichobius caecus Edwards, 1918

Trichobius costalimai Guimarães, 1938

${ }^{*}$ Trichobius diphyllae Wenzel, 1966

${ }^{*}$ Trichobius dugesii Townsend, 1891

*Trichobius galei Wenzel, 1966

*Trichobius hirsutulus Bequaert, 1933

Trichobius intermedius Peterson \& Hurka, 1974

*Trichobius joblingi Wenzel, 1966

${ }^{*}$ Trichobius longipes (Rudow), 1871

Trichobius parasiticus Gervais, 1844

${ }^{*}$ Trichobius sparsus Kessel, 1925

* Trichobius uniformis Curran, 1935

${ }^{*}$ Trichobius undescribed species (dugesii group) from Tonatia saurophila. 


\section{B. List of $\mathbf{4 3}$ Streblid Bat Fly Species Known from Honduras, with Bat Host Associations}

Numbers in parentheses indicate (1) the number of individual flies collected of that fly species and on that host species and (2) the percentage of the total fly individuals collected that were associated with that host species. Associations noted by asterisks are generally considered accidental or contamination transfers and are determined by reference to general patterns of host association among neotropical streblid flies $[1,2,4,29]$; refer to species accounts for additional information:

Anastrebla modestini (1)

Glossophaga soricina (1) (100\%)

Anatrichobius scorzai (6 specimens)

Myotis keaysi (6) (100\%)

Aspidoptera falcata (39)

Sturnira lilium (23) (60\%)

S. ludovici (15) (38.5\%)

* Noctilio leporinus (1) (2.5\%)

Aspidoptera phyllostomatis (14) Artibeus jamaicensis (10) (71.4\%)

${ }^{*}$ A. lituratus (3) (21.4\%)

* Glossophaga soricina (1) (7.1\%)

Exastinion clovisi (5)

Anoura geoffroyi (5) (100\%)

Mastoptera guimaraesi (3)

Phyllostomus hastatus (3) (100\%)

Mastoptera minuta (5)

Lophostoma silvicolum (5) (100\%)

Mastoptera sp. (23)

Lophostoma brasiliense (23) (100\%)

Megistopoda aranea (31)

Artibeus jamaicensis (22) (71\%)

A. intermedius (7) (22.6\%)

${ }^{*}$ A. lituratus (1) (3.2\%)

* Glossophaga soricina (1) (3.2\%)

Megistopoda proxima (58)

Sturnira lilium (50) (86.2\%)

* Artibeus lituratus (3) (5.2\%)

* Glossophaga commisarisi (3) (5.2\%)

${ }^{*}$ G. soricina (1) $(1.7 \%)$

* Dermanura phaeotis (1) (1.7\%)

Megistopoda theodori (52)

Sturnira ludovici (51) (98.1\%)

* Uroderma bilobatum (1) (1.9\%)
Metelasmus pseudopterus (4)

Artibeus jamaicensis (2) (50\%)

A. lituratus (1) (25\%)

${ }^{*}$ Carollia sowelli (1) (25\%)

Neotrichobius stenopterus (3)

Dermanura phaeotis (2) (67\%)

D. toltecus (1) (33\%)

Noctiliostrebla traubi (34)

Noctilio leporinus (34) (100\%)

Nycterophilia coxata (362)

Pteronotus parnellii (361) (99.7\%)

* Sturnira lilium (1) (0.3\%)

Paradyschiria fusca (43)

Noctilio leporinus (43) (100\%)

Paradyschiria parvuloides (10)

Noctilio albiventris (10) (100\%)

Paraeuctenodes longipes (3)

Glossophaga commisarisi (2) (67\%)

G. soricina (1) (33\%)

Paratrichobius dunni (3)

Uroderma bilobatum (2) (67\%)

* Dermanura phaeotis (1) (33\%)

Paratrichobius longicrus (14)

Artibeus lituratus (8) (57\%)

${ }^{*}$ A. intermedius (4) (29\%)

*Sturnira ludovici (2) (14\%)

Paratrichobius sp. (salvini complex) (1) Platyrrhinus helleri (1) (100\%)

Speiseria ambigua (9)

Carollia sowelli (8) (89\%)

* Mimon cozumelae (1) (11\%)

Speiseria peytonae (1)

Carollia brevicauda (1) (100\%)

Strebla chrotopteri (5)

Chrotopterus auritus (5) (100\%)

Strebla curvata (7)

Glossophaga soricina (6) (86\%)

* Artibeus lituratus (1) (14\%)

Strebla diphyllae (2)

Diphylla ecaudata (2) (100\%)

Strebla galindoi (1)

Tonatia saurophila (1) (100\%)

Strebla guajiro (13)

Carollia sowelli (6) (46\%) 
${ }^{*}$ C. brevicauda (3) (23\%)

C. perspicillata (1) (7.7\%)

* Glossophaga soricina (1) (7.7\%)

${ }^{*}$ Artibeus lituratus (1) (7.7\%)

* unknown host (1) (7.7\%)

Strebla hertigi (5)

Phyllostomus discolor (5) (100\%)

Strebla kohlsi (5)

Lophostoma silvicolum (5) (100\%)

Strebla wiedemanni (69)

Desmodus rotundus (69) $(100 \%)$

Trichobioides perspicillatus (37)

Phyllostomus discolor (37) (100\%)

Trichobius caecus (62)

Pteronotus parnellii (60) (97\%)

* Phyllostomus discolor (2) (3\%)

Trichobius costalimai (75)

Phyllostomus discolor (75) (100\%)

Trichobius diphyllae (2)

Diphylla ecaudata (2) (100\%)

Trichobius dugesii (97)

Glossophaga soricina (90) (93\%)

G. commissarisi (5) (5\%)

${ }^{*}$ G. leachii (1) (1\%)

* Mimon cozumelae (1) (1\%)

Trichobius galei (7)

Natalus stramineus (6) (86\%)

${ }^{*}$ Glossophaga soricina (1) (14\%)

Trichobius hirsutulus (1) Myotis keaysi (1) (100\%)

Trichobius intermedius (64) Artibeus inopinatus (46) (72\%)

A. intermedius (10) (16\%)

${ }^{*}$ A. lituratus (3) (5\%)

* Glossophaga commissarisi (2) (3\%)

* Sturnira lilium (2) (3\%)

A. jamaicensis (1) (2\%)

Trichobius joblingi (142)

Carollia sowelli (121) (85\%)

C. subrufa (9) (6\%)

C. perspicillata (7) (5\%)

C. brevicauda (4) (3\%)

${ }^{*}$ C. castanea (1) (1\%)

Trichobius longipes (3) Phyllostomus hastatus (3) (100\%)

\author{
Trichobius parasiticus (857) \\ Desmodus rotundus (842) (98.3\%) \\ * Pteronotus parnellii (10) (1.2\%) \\ ${ }^{*}$ Rhynchonycteris naso (3) (0.1\%) \\ * Phyllostomus discolor (1) (0.1\%) \\ * Artibeus intermedius (1) (0.1\%)
}

Trichobius sparsus (16)

${ }^{*}$ Carollia sowelli (11) (69\%)

Pteronotus parnellii (5) (31\%)

Trichobius uniformis (37)

Glossophaga soricina (29) (78\%)

G. commissarisi (6) (16\%)

* Artibeus lituratus (1) (3\%)

* Mimon cozumelae (1) (3\%)

Trichobius undescribed species (dugesii group) (5) Tonatia saurophila (5) (100\%).

\section{Acknowledgments}

For access to field and specimens, the author thanks R. D. Bradley, R. A. Van Den Bussche, M. Hamilton, T. J. McCarthy, and R. P. Eckerlin. Mr. Eric Stamper assembled the map. Collections were supported in part by a grant from J. Sowell. The author was supported in part by the National Science Foundation (DBI-0545051, DEB-0640330/1, DEB-1003459) and by Western Kentucky University (RCAP 11-8020).

\section{References}

[1] R. L. Wenzel, V. J. Tipton, and A. Kiewlicz, "The streblid batflies of Panama (Diptera: Calypterae: Streblidae)," in Ectoparasites of Panama, R. L. Wenzel and V. J. Tipton, Eds., pp. 405-675, Field Museum of Natural History, Chicago, Ill, USA, 1966.

[2] C. W. Dick, "High host specificity of obligate ectoparasites," Ecological Entomology, vol. 32, no. 5, pp. 446-450, 2007.

[3] C. W. Dick and B. D. Patterson, "Against all odds: explaining high host specificity in dispersal-prone parasites," International Journal for Parasitology, vol. 37, no. 8-9, pp. 871-876, 2007.

[4] R. L. Wenzel, The Streblid Batflies of Venezuela (Diptera: Streblidae), vol. 20 of Brigham Young University Science Bulletin, Brigham Young University, 1976.

[5] B. D. Patterson, J. W. O. Ballard, and R. L. Wenzel, "Distributional evidence for cospeciation between neotropical bats and their bat fly ectoparasites," Studies on Neotropical Fauna and Environment, vol. 33, no. 2-3, pp. 76-84, 1998.

[6] R. L. Wenzel and B. V. Peterson, "Streblidae," in Manual of Nearctic Diptera, J. F. McAlpine, B. V. Peterson, G. E. Shewell, H. J. Teskey, J. R. Vockeroth, and D. M. Wood, Eds., vol. 2 of Monograph, pp. 1293-1301, Research Branch, Agriculture Canada, 1987.

[7] C. A. Komeno and A. X. Linhares, "Batflies parasitic on some phyllostomid bats in southeastern Brazil: parasitism rates and host-parasite relationships," Memórias do Instituto Oswaldo Cruz, vol. 94, no. 2, pp. 151-156, 1999. 
[8] B. D. Patterson, C. W. Dick, and K. Dittmar, "Roosting habits of bats affect their parasitism by bat flies (Diptera: Streblidae)," Journal of Tropical Ecology, vol. 23, no. 2, pp. 177-189, 2007.

[9] A. Ross, "Biological studies on bat ectoparasites of the genus Trichobius (Diptera: Streblidae) in North America, North of Mexico," The Wasmann Journal of Biology, vol. 19, pp. 229-246, 1961.

[10] G. N. Fritz, "Biology and ecology of bat flies (Diptera: Streblidae) on bats in the genus Carollia," Journal of Medical Entomology, vol. 20, no. 1, pp. 1-10, 1983.

[11] A. X. Linhares and C. A. Komeno, "Trichobius joblingi, Aspidoptera falcata, and Megistopoda proxima (Diptera: Streblidae) parasitic on Carollia perspicillata and Sturnira lillium [sic] (Chiroptera: Phyllostomidae) in southeastern Brazil: sex ratios, seasonality, host site preference, and effect of parasitism on the host," Journal of Parasitology, vol. 86, no. 1, pp. 167-170, 2000.

[12] C. W. Dick and J. A. Miller, "Streblidae," in Manual of Central American Diptera, B. V. Brown, A. Borkent, J. M. Cumming, D. M. Wood, N. E. Woodley, and M. Zumbado, Eds., vol. 2, pp. 1249-1260, National Research Council Press, Ottawa, Canada, 2010.

[13] R. Guerrero, "Catálogo de los Streblidae (Diptera: Pupipara) parásitos de murciélagos (Mammalia: Chiroptera) del Nuevo Mundo. I. Clave para los géneros y Nycterophiliinae," Acta Biologica Venezuelica, vol. 14, pp. 61-75, 1993.

[14] G. Graciolli and C. J. B. de Carvalho, "Moscas ectoparásitas (Diptera, Hippoboscoidea) de morcegos (Mammalia, Chiroptera) do Estado do Paraná. II. Streblidae. Chave pictórica para gêneros e espécies," Revista Brasileira de Zoología, vol. 18, pp. 907-960, 2001.

[15] R. Guerrero, "Catálogo de los Streblidae (Diptera: Pupipara) parásitos de murciélagos (Mammalia: Chiroptera) del Nuevo Mundo. IV. Trichobiinae con alas desarrolladas," Boletín de Entomología Venezolana, vol. 9, pp. 161-192, 1994.

[16] R. Guerrero, "Catálogo de los Streblidae (Diptera: Pupipara) parásitos de murciélagos (Mammalia: Chiroptera) del Nuevo Mundo. II. Los grupos: pallidus, caecus, major, uniformis $y$ longipes del género Trichobius Gervais, 1844," Acta Biologica Venezuelica, vol. 15, pp. 1-18, 1994.

[17] R. Guerrero, "Catálogo de los Streblidae (Diptera: Pupipara) parásitos de murciélagos (Mammalia: Chiroptera) del Nuevo Mundo. III. Los grupos: dugesii, dunni y phyllostomae del género Trichobius Gervais, 1844," Acta Biologica Venezuelica, vol. 15, pp. 1-27, 1995.

[18] R. Guerrero, “Catálogo de los Streblidae (Diptera: Pupipara) parásitos de murciélagos (Mammalia: Chiroptera) del Nuevo Mundo. V. Trichobiinae con alas reducidas o ausentes y miscelaneos.", Boletín de Entomología Venezolana, vol. 10, pp. 135-160, 1995.

[19] R. Guerrero, "Catálogo de los Streblidae (Diptera: Pupipara) parásitos de murciélagos (Mammalia: Chiroptera) del Nuevo Mundo. VI. Streblinae," Acta Biologica Venezuelica, vol. 16, pp. 1-25, 1996.

[20] R. L. Wenzel, "Family streblidae," in A Catalogue of the Diptera of the Americas South of the United States, N. Papavero, Ed., pp. 100.1-100.25, Museu de Zoologia, Universidade de São Paulo, São Paulo, Brazil, 1970.

[21] B. V. Peterson and K. Hůrka, "Ten new species of bat flies of the genus Trichobius (Diptera: Streblidae)," The Canadian Entomologist, vol. 106, pp. 1049-1066, 1974.

[22] C. W. Dick, "The streblid bat flies (Diptera: Streblidae) of Guatemala," in Biodiversidad de Guatemala, E. Cano, Ed., vol.
1, pp. 441-452, Universidad del Valle de Guatemala, Guatemala City, Guatemala, 2006.

[23] R. Guerrero, "Catalogo de los Streblidae (Diptera: Pupipara) parásitos de murciélagos (Mammalia: Chiroptera) del nuevo mundo. VII. Lista de especies, hospedadores y paises," Acta Biologica Venezuelica, vol. 17, pp. 9-24, 1997.

[24] N. B. Simmons, "Order chiroptera," in Mammal Species of the World. A Taxonomic and Geographic Reference, D. E. Wilson and D. M. Reeder, Eds., p. 2142, Johns Hopkins University Press, 3rd edition, 2005.

[25] C. W. Dick, Ecology and host specificity of bat flies (Diptera: Streblidae) and their chiropteran hosts [Ph.D. dissertation], Texas Tech University, Lubbock, Tex, USA, 2005.

[26] G. Graciolli and C. W. Dick, "A new species of Metelasmus (Diptera: Streblidae: Streblinae) from southern South America," Zootaxa, vol. 509, pp. 1-8, 2004.

[27] R. L. Wenzel and V. J. Tipton, "Some relationships between mammal hosts and their ectoparasites," in Ectoparasites of Panama, R. L. Wenzel and V. J. Tipton, Eds., pp. 677-723, Field Museum of Natural History, Chicago, Ill, USA.

[28] G. Graciolli, "Nova espécie de Anatrichobius Wenzel, 1966 (Diptera, Streblidae) do Brasil meridional," Revista Brasileira de Entomologia, vol. 47, pp. 55-58, 2003.

[29] C. W. Dick and D. Gettinger, "A faunal survey of streblid flies (Diptera: Streblidae) associated with bats in Paraguay," Journal of Parasitology, vol. 91, no. 5, pp. 1015-1024, 2005.

[30] J. A. Miller and M. Tschapka, "The bat flies of La Selva (Diptera: Nycteribiidae, Streblidae). Version 1.1," Universität Ulm, Ulm, Germany, 2009, http://www.biologie.uni-ulm.de/bio3/Batfly/index.html.

[31] R. Guerrero, "Notes on Neotropical batflies (Diptera, Streblidae). I. The genus Trichobius, with description of two new species and one new subspecies from Venezuela," Acta Parasitologica, vol. 43, no. 2, pp. 86-93, 1998.

[32] G. Graciolli, Taxonomia de Streblidae, Nycteribiidae (Diptera, Hippoboscoidea) e parasitismo sobre as espécies de Artibeus Leach (Chiroptera, Phyllostomidae) na Região Sul do Brasil e asociação histórica entre Trichobius grupo phyllostomae com seus hospedeiros [Ph.D. dissertation], Universidade Federal do Paraná, Paraná, Brazil, 2004.

[33] IUCN Global Species Programme Red List Unit, Cambridge, UK, 2012, http://www.iucnredlist.org/.

[34] T. J. McCarthy and S. G. Perez, "Land and freshwater mammals of: faunal documentation and diversity," in Biodiversidad de Guatemala, E. Cano, Ed., vol. 1, pp. 625-674, Universidad del Valle de Guatemala, Guatemala City, Guatemala, 2006.

[35] H. M. ter Hofstede, M. B. Fenton, and J. O. Whitaker Jr., "Host and host-site specificity of bat flies (Diptera: Streblidae and Nycteribiidae) on Neotropical bats (Chiroptera)," Canadian Journal of Zoology, vol. 82, no. 4, pp. 616-626, 2004. 

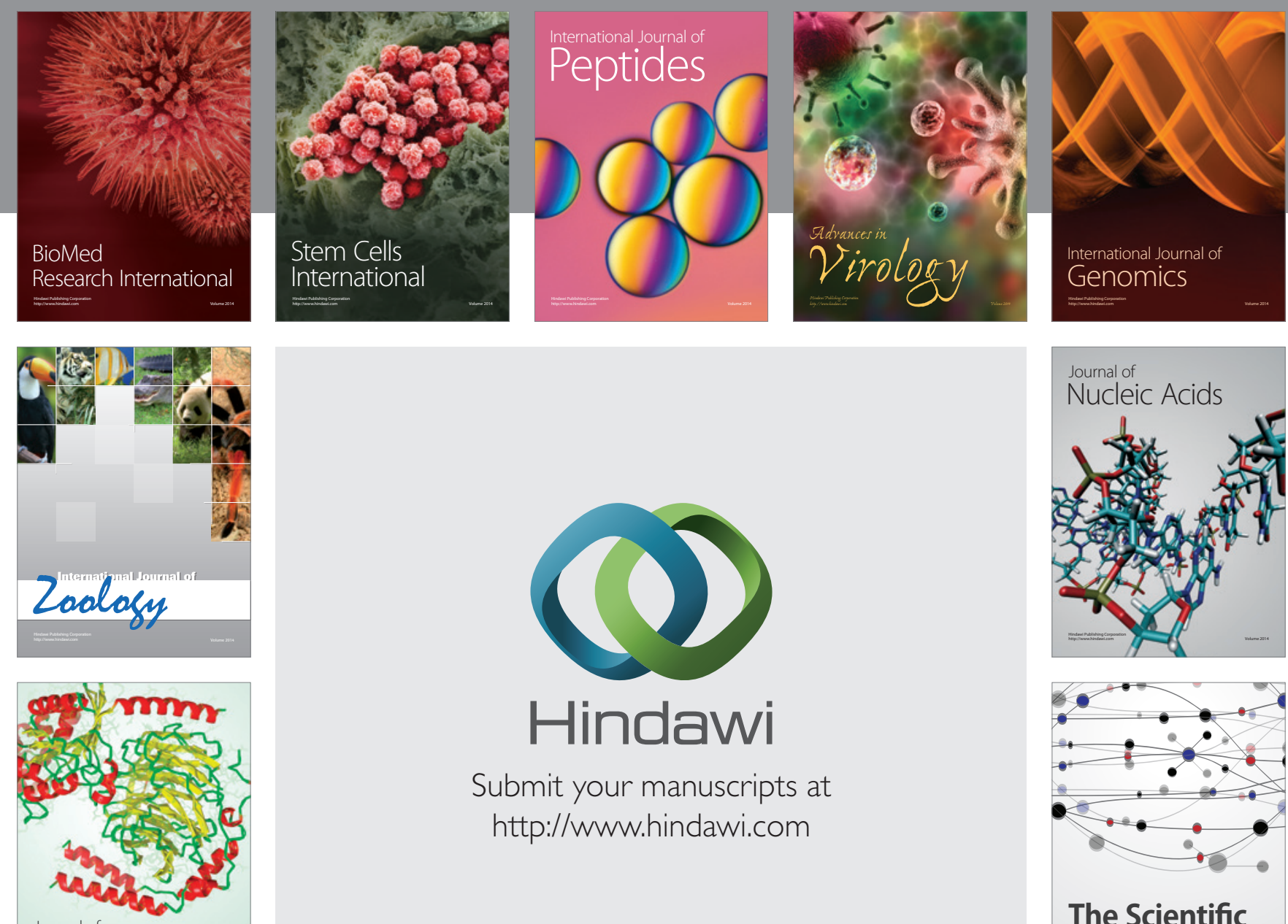

Submit your manuscripts at

http://www.hindawi.com

Journal of
Signal Transduction
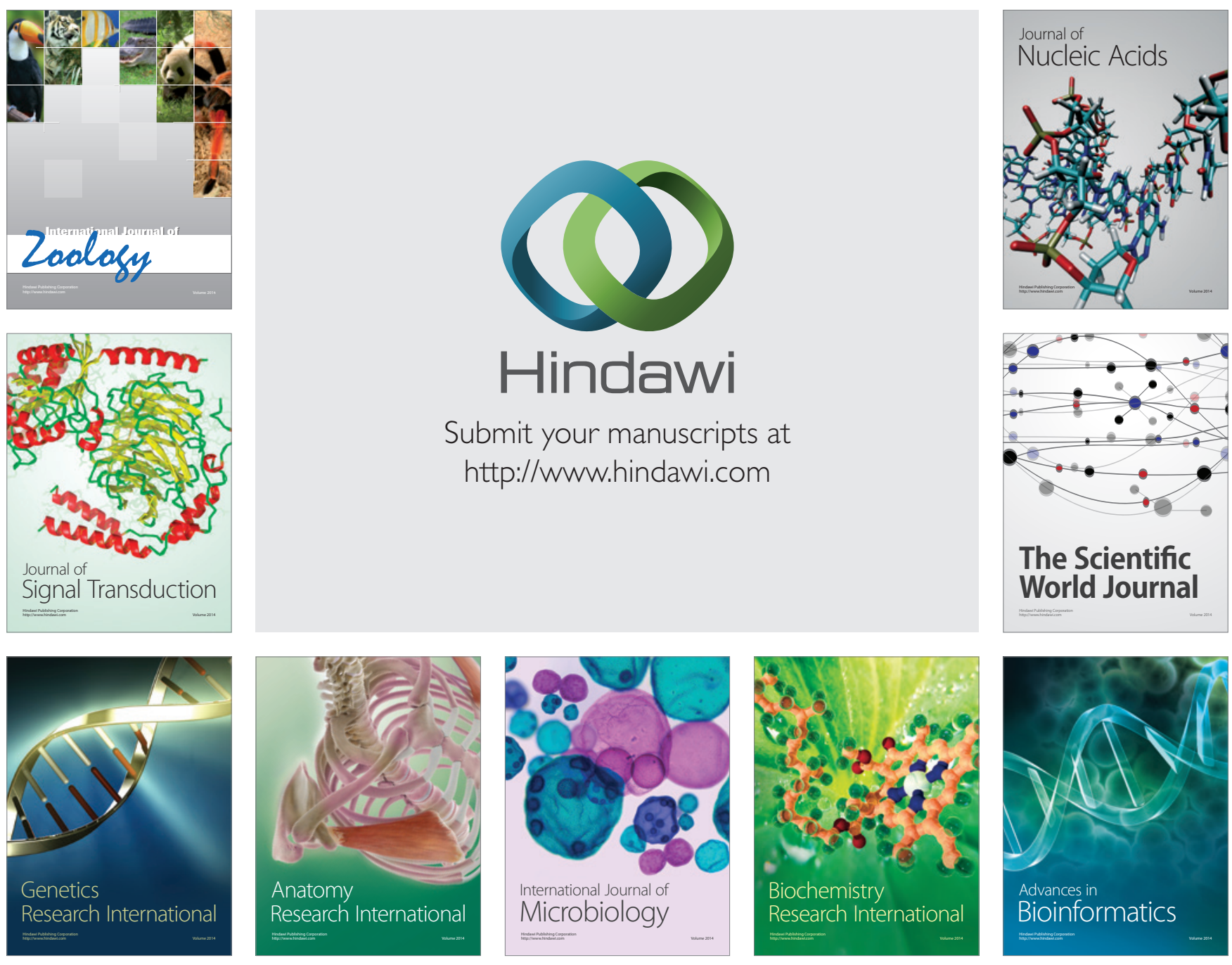

The Scientific World Journal
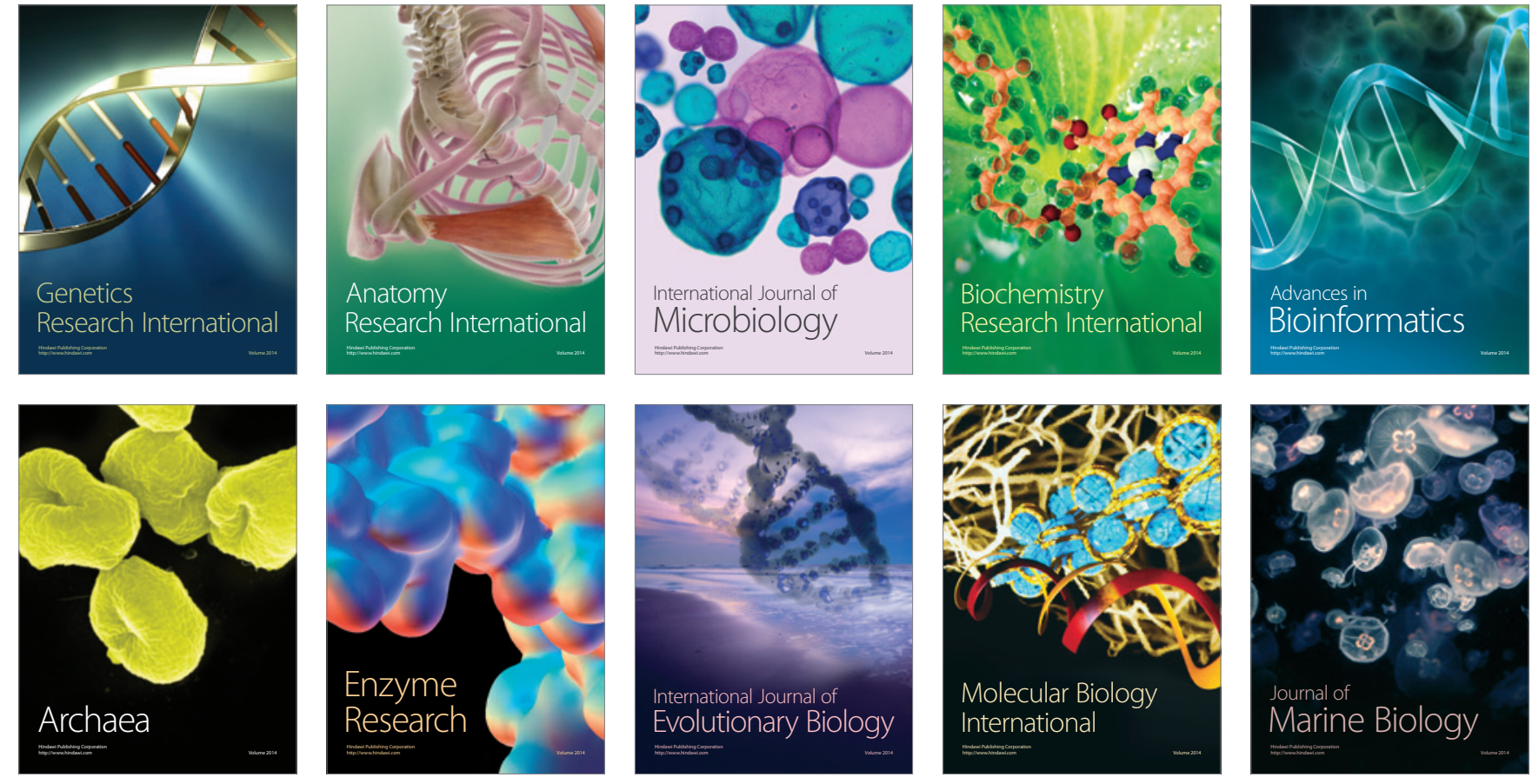